\title{
Global spatial distribution of natural riverine silica inputs to the coastal zone
}

\author{
H. H. Dürr ${ }^{1,2,3}$, M. Meybeck ${ }^{2}$, J. Hartmann ${ }^{4,6}$, G. G. Laruelle ${ }^{5}$, and V. Roubeix ${ }^{3,7}$ \\ ${ }^{1}$ Department of Physical Geography, Faculty of Geosciences, Utrecht University, The Netherlands \\ ${ }^{2}$ UMR 7619 Sisyphe, Université Pierre et Marie Curie (Paris VI), Paris, France \\ ${ }^{3}$ ESA (Ecologie des Systèmes Aquatiques), Université Libre de Bruxelles, Belgium \\ ${ }^{4}$ Institute for Applied Geosciences, Darmstadt University of Technology, Germany \\ ${ }^{5}$ Department of Earth Sciences - Geochemistry, Faculty of Geosciences, Utrecht University, The Netherlands \\ ${ }^{6}$ Institute for Biogeochemistry \& Marine Chemistry, KlimaCampus, Universität Hamburg, Germany \\ ${ }^{7}$ Cemagref Bordeaux, Gazinet-Cestas, France
}

Received: 1 October 2008 - Published in Biogeosciences Discuss.: 27 January 2009

Revised: 8 January 2011 - Accepted: 19 January 2011 - Published: 7 March 2011

\begin{abstract}
Silica, $\mathrm{SiO}_{2}$, in dissolved (DSi) and particulate (PSi) form, is both a major product of continental weathering as well as an essential nutrient in terrestrial and aquatic systems. Here we present estimates of the spatial distribution of riverine silica fluxes under natural conditions, i.e. without human influence, to $\sim 140$ segments of the global coastal zone. Focussing on the construction of the DSi budget, natural DSi concentration is multiplied with discharge of rivers for each segment for documented basins and segments. Segments with no documentation available are estimated using clustered information based mainly on considerations of local lithology, climate, and lake retention. We approximate fluxes of particulate silica in various forms (PSi) from fluxes of suspended matter, calculated from existing models. Results have been established for silica fluxes, concentrations and yields for drainage basins of the different continents, oceans basins as well as coastal segment basins. For the continental surfaces actually draining into the oceans (exorheic regions, representing 114.7 million $(\mathrm{M}) \mathrm{km}^{2}$ ), $371 \mathrm{M} \mathrm{ty}^{-1}$ of DSi and $8835 \mathrm{M} \mathrm{ty}^{-1}$ of PSi are transported, corresponding to a mean concentration of $9.5 \mathrm{mg} \mathrm{l}^{-1}$ and $226 \mathrm{mg} \mathrm{l}^{-1}$, and to a mean yield of $3.3 \mathrm{t} \mathrm{km}^{-2} \mathrm{y}^{-1}$ and $77 \mathrm{t} \mathrm{km}^{-2} \mathrm{y}^{-1}$, respectively. DSi yields exceeding $6.6 \mathrm{t} \mathrm{km}^{-2} \mathrm{y}^{-1}$, i.e. $>2 \times$ the global average, represent $17.4 \%$ of the global continental icefree exorheic area but correspond to $56.0 \%$ of DSi fluxes. Pacific catchments hold most of the hyper-active areas ( $>5 \times$ global average), suggesting a close connection between tec-
\end{abstract}

Correspondence to: H. H. Dürr (h.durr@geo.uu.nl) tonic activity and DSi fluxes resulting from silicate weathering. The macro-filters of regional and marginal seas intercept $33 \%$ and $46 \%$ of the total dissolved and particulate silica fluxes. The mass of DSi received from rivers per unit square area of various oceans ranges over more than one order of magnitude. When expressed per unit volume and when individual regional seas are considered this figure ranges over two to three orders of magnitude, an illustration of the heterogeneity of the land to sea connection.

\section{Introduction}

Dissolved silica $\left(\mathrm{SiO}_{2}\right.$ or $\mathrm{DSi}$, expressed as $\mathrm{mg} \mathrm{SiO}_{2} 1^{-1}$ throughout this paper unless noted) is one of the major nutrients of continental aquatic systems (Schelske and Stoermer, 1971) and of marine systems (Tréguer et al., 1995), essential to the development of diatoms, radiolarians and sponges (Schlesinger, 1997). Silica is also a major component of the total dissolved solids found in continental waters resulting from the chemical weathering of soils and surficial rocks. As such, it provides information on weathering processes and rates (Wollast and Mackenzie, 1983; Gaillardet et al., 1999) and has been analysed since the 19th century by European geologists and chemists. Perhaps the first comprehensive overview of silica in the environment (rock, soils, springs, rivers and the ocean) is provided by the German geologist Roth $(1879,1893)$. In the early 1900 's, both geochemists, as the US Geological Survey pioneers (Clarke, 1924) and freshwater ecologists since the 1960's (Schelske, 1985; Wetzel, 2001) enhanced the knowledge of silica in the environment.

Published by Copernicus Publications on behalf of the European Geosciences Union. 


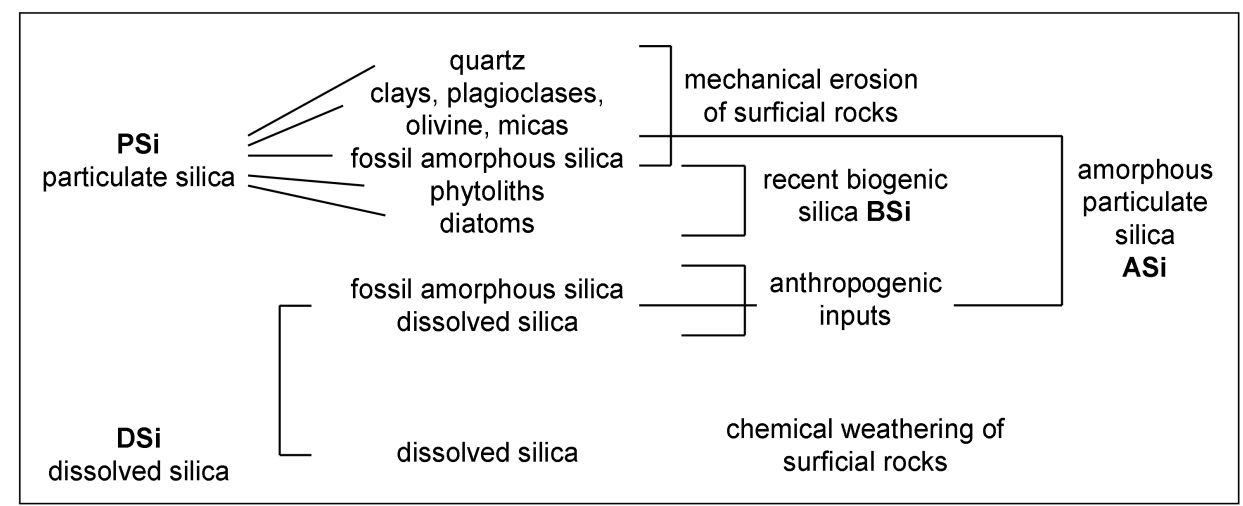

Fig. 1. Sources and forms of riverine silica.

In the last 25 years there has been a growing evidence of another major silica cycle in the terrestrial vegetation, litter and soils through the uptake and storage of silica in phytoliths (Bartoli, 1983; Meunier et al., 1999; Conley, 2002). Part of the phytoliths is not recycled and may be eroded, as the soil organic matter, and carried by rivers. Freshwater diatoms, living and as detritus, are also considered as biogenic particulate silica (BSi). It can be identified and quantified through visual analysis, a long and tedious procedure. A chemical proxy for BSi has been proposed, using a soda extraction (Paasche, 1973 modified by Nelson et al., 1989; Isaji, 2003; Saccone et al., 2006). The silica extracted by this method is referred to as amorphous silica (ASi).

In open ocean waters, $\mathrm{ASi}$ and BSi are nearly identical as there is little non-biogenic amorphous silica. Exceptions may temporarily occur in case significant amounts of long-range atmospheric dust, containing fly ash, are deposited on surface waters, as for East Asia downwind regions (e.g., Hartmann et al., 2008). For riverine material, ASi and BSi are not always identical as detrital amorphous silica can also originate from the mechanical erosion of sedimentary rocks and soils (e.g. chalk, cherts). Finally, there is an anthropogenic component of the silica cycle: either from diatomite earth mined from past lacustrine deposits, or artificially produced zeolith (Breese, 1994; van Dokkum et al., 2004). They are used in industries (pulp and paper production, water and waste water treatment, soil stabilization), pharmaceuticals and household products (mainly zeolith in detergents) and likely to reach the aquatic system either as dissolved or as particulate silica. A further impact of Humans on the silica cycle is the additional retention of BSi by reservoirs, mainly as diatoms detritus (Humborg et al., 2000; Straskrabova et al., 2003). This process is identical to the silica retention in natural lakes (Wetzel, 2001).

The dissolved silica fluxes are generally inferior to the particulate silica fluxes generated by the mechanical erosion of silica-containing minerals from soils and rocks (cf. Garrels and Mackenzie, 1971; Garrels et al., 1973; Martin and
Meybeck, 1979). River inorganic silicon-containing particulates of non-biogenic origin are composed mostly by quartz, feldspar or clay minerals (illite, chlorite, kaolinite, etc.) (e.g., Subramanian, 1980; Gölz, 1982; Gaiero et al., 2004). Minerals most resistant to chemical weathering are characterised by increased proportions in suspended matter, if compared to unweathered source rocks of a river catchment. Sometimes fine fragments of eroded rocks may contain amorphous detrital silica. All silica-containing components, including phytoliths and BSi, are part of the particulate silica (PSi), analysed after a complete digestion of river particulates.

There are therefore multiple ways to consider the riverine silica, from the analytical chemist, the ecologist, the geochemist, and the physical geographer (Fig. 1).

Since the first estimates of dissolved silica concentrations in rivers by Roth (1879) and Clarke (1924), there have been few studies on this topic, compared to the ones on nitrogen and phosphorus (Livingstone, 1963; Meybeck, 1979, 1987, 1988; Probst, 1992; Tréguer et al., 1995 and the special issue of Global Biogeochemical Cycles, edited by Seitzinger et al., 2005). Previous DSi budgets are not or little spatialized (e.g., Jennerjahn et al., 2006) while other nutrients and carbon budgets have been gradually spatialized over the last 15 years, first at the $2^{\circ} \times 2^{\circ}$ resolution, then at $0.5^{\circ} \times 0.5^{\circ}$ (Ludwig et al., 1996; Amiotte-Suchet et al., 2003; Green et al., 2004; Seitzinger et al., 2005). The first model-based spatially explicit DSi budget (Beusen et al., 2009) is based on the data presented here. Many of these recent spatialized nutrient budgets are based on a general register of river inputs to oceans, GEMS-GLORI (Meybeck and Ragu, 1995) that lists about 500 individual rivers with various levels of documentation.

In the case of spatially explicit model budgets for dissolved and particulate matter, in general monitoring data of the $\sim 60-120$ largest rivers draining to coastal waters are applied for model calibration and small catchments information is neglected. However, some studies provide evidence that regions characterised by small catchments draining to coastal 
zones in humid and warm climates (with a specific lithologic characteristic) represent above average specific fluxes (Milliman and Syvitski, 1992; Hartmann et al., 2009, 2010a). In particular, the Ring of Fire, surrounding the Pacific Ocean, is characterised by small and steep catchments due to plate tectonics.

The only existing detailed global river data base on dissolved and particulate matter (Meybeck and Ragu, 1995) is also partly used here for the emphasized dissolved silica budget in order to

i. reach a global spatial distribution of natural - i.e. without (or low) human influence - river dissolved silica concentrations and fluxes at the regional level $(\sim$ one million square kilometres);

ii. compare these with the particulate silica fluxes;

iii. identify areas most contributing to the global budget;

iv. discuss the net silica inputs to oceans, focusing on DSi.

We therefore consider the following steps:

i. collection and selection of individual DSi and PSi data for major and some minor rivers at the global scale, with a clear focus on constructing the DSi budget based on the earliest data available in order to avoid human overprint;

ii. extrapolation of documented data at regional resolution using a previously introduced coastal catchments delineation (COSCATs) (Meybeck et al., 2006), and calculation of silica river fluxes for each coastal catchment;

iii. spatial analysis of silica fluxes from continents, for open oceans and regional seas, according to the methodology defined by Meybeck et al. (2007) and Meybeck and Dürr (2009).

The data compiled and the results presented here, have been used in several applications: Bernard et al. (2011) used the spatialized data as input for an OGCM. Beusen et al. (2009) used the data for a statistical approach on control factors of global DSi fluxes. Laruelle et al. (2009) used the data for an assessment of the global biogeochemical silicon cycle. Also regional studies may benefit as they need spatialized data for comparison with other, similar regions (e.g., Hartmann et al., 2009; Jansen et al., 2010). We also identify here major regional seas as significant filters of land-ocean DSi fluxes. The budget of DSi reaching the open ocean is significantly different from the amount that is delivered at river mouths to the coastal zones.

\section{Data and methodology}

\subsection{Database for DSi and PSi in river waters and particulate matter}

The dissolved silica found in continental waters originates from the chemical weathering of a great number of minerals, from the more easily weathered (e.g., volcanic glass, olivine) to the least (e.g. clays, quartz) (cf. Wollast and Mackenzie, 1983; Meybeck, 1987; Stallard, 1995). The weatherability of minerals generally has a stronger control on DSi mobilization from rocks than the silica content of the various, distinguished rock types or lithological classes (cf. Hartmann et al., 2010a, 2011). In general, the levels of silica concentrations transported from the terrestrial to the fluvial system depend on the relative proportions of minerals in soils and rocks and their weatherability, on temperature, water residence time in soils and rocks, drainage intensity, gradient of slope, land use/cover changes and acids involved in weathering processes, as e.g., carbonic, sulphuric or humic acids (Meybeck, 1979; Wollast and Mackenzie, 1983; Drever, 1994, 1997; Gaillardet et al., 1999; West et al., 2005; Jennerjahn et al., 2006; Conley et al., 2008; Hartmann et al., 2010a; Struyf et al., 2010; Cornelis et al., 2011).

The yield of dissolved silica exported by rivers per unit area $\left(\mathrm{t} \mathrm{SiO}_{2} \mathrm{~km}^{-2} \mathrm{y}^{-1}\right)$ is first dependant on the river runoff $\left(\mathrm{mm} \mathrm{y}^{-1}\right)$, then on the control factors of concentration (Wollast and Mackenzie, 1983; Meybeck, 1994; Hartmann et al., 2010a and b; Cornelis et al., 2011).

The retention of silica in river systems, e.g. in lakes and flood plains, is linked to their trophic state (for DSi), to lake abundance, expressed by the limnic index (\% of lake cover in a given area, i.e. \% of area covered by lakes with respect to the total catchment basin area - this value can attain up to $20 \%$ at the $\sim 1 \mathrm{M} \mathrm{km}^{2}$ scale regarded here) (Conley et al., 2000), and by deposition of ASi in alluvial plains (Admiraal et al., 1990). The commonly reported retention for DSi extends from 4 to more than $100 \mathrm{~g} \mathrm{SiO}_{2}$, with a median value of $20 \pm 10 \mathrm{~g} \mathrm{SiO}_{2}$, per year per $\mathrm{m}^{2}$ of lake area (Campy and Meybeck, 1995). Apart from the formerly glaciated shields in Canada, Northern Europe and Taymir Peninsula (Siberia), where it commonly ranges between 5 and $20 \%$, the limnic index rarely exceeds few percent in other parts of the world (Meybeck, 1995).

In order to construct the DSi database, dissolved silica concentrations are first selected from the Meybeck and Ragu (1995) catalogue of river inputs to oceans ("GEMSGLORI", www.gemswater.org). They selected 1 to 3 average analyses for the same river, depending on authors and period of records, in which we generally took the earliest silica average. We also used another data set on pristine rivers of the world (PRISRI, see the Supplement), already used by Meybeck (2003), to determine the control factors of river chemistry in natural conditions. In this second data set numerous important references on river chemistry prior 1950/1960 
are given and reported here in our Supplement, i.e. before the main development of large reservoirs on world rivers (Vörösmarty et al., 1997), as (i) works on US rivers from a dozen of US Geological Survey reports prior to 1940, most of them used and cited by Clarke (1924), (ii) former Soviet rivers analysed between 1940 and 1960 by Alekin and Brazhnikova (1960, 1962 and 1968) and (iii) June Kobayashi's work on Asian rivers in the same period for Japan, Thailand, Indonesia, Sri Lanka (Kobayashi, 1959, 1960 and 1966). We also selected more recent analyses in regions with limited human impacts as in Alaska and Canada (Brunskill, 1986), Amazon and Orinoco basins (Lewis and Saunders, 1989), Patagonia (Depetris and Paolini, 1991), in West and South Africa (de Villiers, 1962; Olivry and Noah, 1978; Orange, 1992). Most of the presented analyses thus have a date before 1980/1990. Some carefully selected personnel communications were added where we could not track the original data source. The detailed list of references is given in Supplement $1 \mathrm{~A}$ to $\mathrm{F}$ for each river.

Measuring dissolved silica is a relatively simple and standard colorimetric method, used since tens of years (e.g., Robinson and Thompson, 1948; Strickland et al., 1968; Koroleff, 1983). Contrary to other substances (as ammonium) potential error sources are small, and we believe that using relatively old data does not present a particular bias as to measuring methods. Furthermore, the data used and the according sources were included in a substantial data quality control and standardization efforts, based on principles used in previous studies (Meybeck and Ragu, 1995; Meybeck, 2003). For example, sufficient inter- and intra-annual data must be present to assure representative annual averages. Meybeck and Ragu (1995) have explained the detailed data quality requirements for the Gems-Glori database, which has been designed using a similar approach. The pristine river database used here follows the same data quality requirements (Meybeck, 2003), with the additional requirement that as little human influence as possible can be detected, and hence often the oldest available data have been recognized as more appropriate to avoid as far as possible human influences due to the construction of dams or eutrophication. As the documentation of all procedures for the data sampling, measurement, etc. is beyond the appropriate space and scope of this paper, we refer to the references provided.

Particulate silica (PSi) in rivers is not analysed within most water quality surveys as it is not listed as an indicator of contamination: it must be collected for each river from individual papers dealing with suspended particulate matter (SPM) chemistry. The total particulate silica obtained after complete digestion of filters or of dried sediments is the most common element found in any SPM analysis although it is not much analysed in academic literature, instead heavy metals and rare earth elements (REE) are the most commonly analysed. In case of large proportions of carbonate rocks in the river catchment, most of the carbonate minerals are dissolved during chemical weathering and only the insoluble material
- e.g., clays - is carried with SPM together with some fine carbonate detritus (e.g., Gölz, 1982). In the example case of France, the average $\mathrm{SiO}_{2}$ concentration (DSi) in limestone and dolomite draining streams is 3.6 and $4.0 \mathrm{mg} \mathrm{l}^{-1}$, respectively, and can go up to $12.0 \mathrm{mg}^{-1}$ for chalk basins due to the presence of amorphous silica in this rock type; in gypsum marl DSi can also be high, between 8.0 and $9.6 \mathrm{mg} \mathrm{l}^{-1}$ (Meybeck, 1986, 2003). As a result, even carbonated river basins do export particulate silica. The coarse fraction of river particulates that transits as bed load consists of quartz with few percent of heavy minerals.

As a result, in medium to large rivers silica is largely dominating all other elements in particulates (Martin and Meybeck, 1979; Canfield, 1997). Several world averages have been proposed for silica since 1979, they are very similar despite the growing data base: Gordeev and Lisitzin (1978) $255000 \mathrm{ppm}$, Martin and Meybeck (1979) $285000 \mathrm{ppm}$, Glazovsky (1990) $254000 \mathrm{ppm}$. Viers et al. (2009) compiled a new global database on the chemical composition of suspended sediment fluxes, they found a quite similar value for Si content $(254000 \mathrm{ppm}$, with a variation of $117000 \mathrm{ppm})$. A preliminary survey of hundreds of river analyses for major and trace elements (GLOMET, see the Supplement), based on data from 62 major basins and tributaries from 5 continents and from latitudes ranging from $40^{\circ} \mathrm{S}$ to $65^{\circ} \mathrm{N}$ (containing to a certain amount the same data used in the existing literature), gives a PSi median content of $260000 \mathrm{mg} \mathrm{Si}$ per $\mathrm{kg}$ (or ppm) of river particulates. The major control factor of PSi export by unit river basin area (yield) is therefore the sediment supply that commonly ranges from 10 to $10000 \mathrm{t} \mathrm{km}^{-2} \mathrm{y}^{-1}$ in medium and large rivers (Milliman and Syvitski, 1992). Among more than 50 chemical elements analysed in river particulates, $\mathrm{Si}$ is the least variable, either under different climate conditions or due to rock lithology, for rivers exceeding $10000 \mathrm{~km}^{2}$. Silicium, or silica, is also not largely affected by human impacts in the GLOMET database. The only exception is noted for rivers with very low SPM concentrations due to reservoir settling of detrital material and to the presence of biogenic silica due to diatom growth. The related fluxes at the global scale are quite limited. Therefore, we have considered here as a first approximation a constant PSi content of $260000 \mathrm{mg} \mathrm{Si} \mathrm{kg}^{-1}$, i.e. 55.64 weight $\% \mathrm{SiO}_{2}$, for each coastal catchment, i.e. at the one million $\mathrm{km}^{2}$ resolution at which this budget is realised. In this first estimate the river bed load, which consists mostly of quartz sands and gravel, has not been considered. It is generally higher in steeper headwaters and where mountainous rivers drain quickly to oceans, but this kind of data is seldom reported and is thought not to account significantly in the global budget, often considered as $10 \%$ of the river total sediment transport (cf., Zanke, 1982; Milliman and Syvitski, 1992).

References for the data base on silicon analysis in river SPM and/or freshly deposited fine-grained sediments can be found in the Supplement. 


\subsection{Calculating silica budgets for coastal catchments}

For spatial analysis of material fluxes the exorheic part of the continents can be segmented, as done by Meybeck et al. (2006), resulting in a mega-puzzle of $\sim 140$ pieces, the coastal catchments or COSCATs. These entities have been specifically designed to allow the reporting of global river fluxes of water, of dissolved and particulate materials as nutrients and carbon species, and of contaminants in a standardized way. Previous coastal segmentations are not applicable for river budget reporting, while COSCATs delineations are based on multiple criteria combining basin boundaries, coastal morphology, ocean dynamics, regional seas limits etc. (see a complete discussion in Meybeck et al., 2006). The COSCATs are related to the exorheic part of the $\sim 6200$ individual river basins that have been delineated at the $0.5^{\circ} \times 0.5^{\circ}$ resolution and can be fully described through many databases that have been developed over the last 10 years, in particular within the IGBP-BAHC programme (Vörösmarty and Meybeck, 2004) as the global river network (Vörösmarty et al., 2000a, b), the global scale relief typology (Meybeck et al., 2001), or lithology (Dürr et al., 2005). Of particular importance is the water runoff field at the same resolution, resulting from a global-scale model combined to data from the Global Runoff Data Center at WHO/UNESCO (Fekete et al., 2002).

As such, each segment has a maximum homogeneity in its coastal area. Fixed segment boundaries allow easy description and mapping at coarse resolution and all land to ocean fluxes can be reported in the same format, e.g. for application in Earth System models. The median length of coastline of the segments (at the $0.5^{\circ} \times 0.5^{\circ}$ resolution) is a little over $2000 \mathrm{~km}$, and the mean reach of the segments inland is $360 \mathrm{~km}$ (median $150 \mathrm{~km}$ ). Some of the COSCATs are quite large in area, from 2 to 7 millions (M) $\mathrm{km}^{2}$, since the largest river basins cannot be split as for the Amazon or Congo. The median size of the COSCATs is $0.83 \mathrm{M} \mathrm{km}^{2}$. Each COSCAT is associated to a river runoff $\left(\mathrm{mm} \mathrm{y}^{-1}\right.$ or $\left.\mathrm{km}^{3} \mathrm{y}^{-1}\right)$ that can range from near zero (arheism) to $>2400 \mathrm{~mm} \mathrm{y}^{-1}$ for very humid tropics (Meybeck et al., 2006). COSCATs have a 4 digit coding: the first two digits for individual continents, then for individual COSCATs numbered clockwise. COSCAT names are originating from oceanic and coastal morphological features (see original maps and details in Meybeck et al. (2006) and the auxiliary material pertaining to it). Note that COSCAT boundaries have also been specifically designed to allow for Regional Seas budgets (Meybeck and Dürr, 2009).

For each COSCAT the DSi fluxes result from the following steps:

i. Product of documented DSi concentrations by the related natural river discharges (usually also available in Meybeck and Ragu, 1995; otherwise they are calculated from the Fekete et al. (2002) data set), and calculation of non-documented area and runoff. ii. If the river basin characteristics in the undocumented area are close to the documented ones then these known average concentrations are extrapolated to the remaining part of the COSCAT.

iii. If the undocumented area is much different, a specific river or tributary can be chosen as representative of this area. It may even originate from a nearby COSCAT or river where general basin characteristics are similar. This informational clustering is based on lithology, climate, relief, water drainage, and abundance of lakes, which are the main control factors of silica fluxes (Wollast and Mackenzie, 1983; Meybeck, 1995, 2003; Drever, 1997; Hartmann et al., 2010a). This estimated DSi is then combined to the remaining runoff which can also be different from the one of the documented area (estimated DSi levels are given in Supplement 1 for each COSCAT). For instance, for very large COSCATs where climate and runoff can be heterogeneous, as for the $\mathrm{Ob}$, Yenisseï and Lena, the undocumented coastal basins have not been based on the known DSi in these major rivers, but on much smaller north Siberian rivers that are documented as Khatanga and Olenek, coupled with a much lower runoff.

iv. Few COSCATs remain completely undocumented: here the DSi concentration is chosen from rivers or a group of rivers characterised by similar weathering conditions, including similarity in catchment properties, and attributed to the whole runoff of the undocumented COSCAT.

The resulting discharge-weighted silica concentrations $\mathrm{DSi}^{*}$ $\left(\mathrm{mg} \mathrm{SiO}_{2} \mathrm{l}^{-1}\right)$ and yields $Y_{\mathrm{DSi}}\left(\mathrm{t} \mathrm{SiO}_{2} \mathrm{~km}^{-2} \mathrm{y}^{-1}\right)$ are then calculated for each COSCAT (Eqs. 1 and 2):

$\mathrm{DSi}_{j}^{*}=\left(\Sigma\right.$ fluxes $\left._{\mathrm{cij}}\right) /\left(\operatorname{COSCAT}_{j}\right.$ discharge $)$

$Y_{\mathrm{DSi}_{j}}=\left(\Sigma\right.$ fluxes $\left._{\mathrm{cij}}\right) /\left(\mathrm{COSCAT}_{j}\right.$ area $)$

With "ci" being the running index for catchments within a $\operatorname{COSCAT}_{j}$

The fluxes and yields of particulate silica for each COSCAT have been calculated on the basis of SPM loads estimated from the Ludwig and Probst (1998) model which takes into account several control factors as relief, lithology, runoff, vegetation cover and is used to characterise the particulate inputs for each COSCAT. This spatialized model $\left(0.5^{\circ} \times 0.5^{\circ}\right)$ does not include the sediment trapping in reservoirs which is believed to become more and more important (Vörösmarty et al., 2003; Syvitski et al., 2005), it is therefore compatible with our target of estimating the silica budget as close as possible to pre-anthropogenic conditions. SPM yields and loads are then combined to the median PSi content $\left(260000 \mathrm{mg} \mathrm{Si} \mathrm{kg}^{-1}\right)$ to generate the corresponding PSi yields and loads re-converted into $\mathrm{SiO}_{2}$ (Eq. 3) in order to 
Table 1. Average dissolved and particulate silica fluxes, concentrations (runoff weighted averages) and yields (area weighted averages) for the exorheic parts of the continents. Catchment surface area, discharge and runoff are given as well as \% of volcanic rocks from Dürr et al. (2005). The fraction of PSi that possibly dissolves and becomes biologically available might be $<1 \%$ (see discussion).

\begin{tabular}{lccccccccc}
\hline & $\begin{array}{c}\text { Catchment } \\
\text { area } 10^{6} \mathrm{~km}^{2}\end{array}$ & $\begin{array}{c}\text { Discharge } \\
\mathrm{km}^{3} \mathrm{y}^{-1}\end{array}$ & $\begin{array}{c}\text { Runoff } \\
\mathrm{mm} \mathrm{y}^{-1}\end{array}$ & $\begin{array}{c}\text { Volcanic rocks } \\
(\mathrm{Vb}+\mathrm{Va}+1 / 2 \mathrm{Cl})^{\mathrm{b}} \%\end{array}$ & $\begin{array}{c}\text { DSi mean } \\
\text { concentration } \\
\mathrm{mg} \mathrm{l}^{-1} \mathrm{SiO}_{2}\end{array}$ & $\begin{array}{c}\mathrm{DSi} \text { flux } \\
\mathrm{Mty}^{-1} \\
\mathrm{SiO}_{2}\end{array}$ & $\begin{array}{c}\text { DSi yield } \\
\mathrm{tkm}^{-2} \mathrm{y}^{-1} \\
\mathrm{SiO}_{2}\end{array}$ & $\begin{array}{c}\text { PSi flux } \\
\mathrm{Mty}^{-1} \\
\mathrm{SiO}_{2}\end{array}$ & $\begin{array}{c}\text { PSi yield } \\
\mathrm{km}^{-2} \mathrm{y}^{-1} \\
\mathrm{SiO}_{2}\end{array}$ \\
\hline Africa & 26.2 & 4130 & 157 & 4.2 & 12.6 & 52.1 & 2.0 & 528 & 20.1 \\
Europe $^{\mathrm{a}}$ & 8.4 & 2410 & 285 & 6.9 & 5.6 & 13.5 & 1.6 & 367 & 43.5 \\
North America & 21.9 & 5880 & 268 & 11.3 & 8.0 & 47.2 & 2.2 & 1713 & 78.2 \\
South America & 17.4 & 11850 & 681 & 10.0 & 9.0 & 106.5 & 6.1 & 1633 \\
Asia & 34.0 & 12900 & 379 & 12.8 & 10.0 & 129.4 & 3.8 & 3951 & 116.2 \\
Australasia & 6.7 & 1920 & 284 & 8.4 & 11.8 & 22.6 & 3.3 & 643 & 95.3 \\
Total Exorheic & 114.7 & 39080 & 341 & 9.3 & 9.5 & 371 & 3.3 & 8835 & 77.0 \\
\hline
\end{tabular}

a Including a small non-glaciated fraction of Greenland.

b $\mathrm{Vb}$ - Basic volcanic rocks, Va - Acid volcanic rocks, $\mathrm{Cl}$ - Complex lithology (consisting 1/2 of volcanic rocks, see Dürr et al., 2005).

facilitate the comparison between $Y_{\mathrm{DSi}}$ and $Y_{\mathrm{PSi}}$, both expressed as $\mathrm{SiO}_{2}$ :

$Y_{\mathrm{PSi} j}=Y_{\mathrm{SPM} j} \times 0.26 \times 2.14$

With:

$Y_{\mathrm{SPM} j}=$ sediment yield in $\operatorname{COSCAT}_{j}$ in $\mathrm{tSPM} \mathrm{km}^{-2} \mathrm{y}^{-1}$

$0.26=$ constant factor for all COSCATs: $26 \%$ of $\mathrm{Si}$ in SPM or $260000 \mathrm{ppm} \mathrm{Si}$

$2.14=$ conversion factor from $\mathrm{Si}$ to $\mathrm{SiO}_{2}$.

Example:

$Y_{\mathrm{SPM} x}=100 \mathrm{tkm}^{-2} \mathrm{y}^{-1} \rightarrow Y_{\mathrm{PSi} x}=55.6 \mathrm{tSiO}_{2} \mathrm{~km}^{-2} \mathrm{y}^{-1}$

\section{Results}

The combination of COSCATs and their silica budgets allows for the calculation of various types of budgets: per continent, per ocean drainage basin, per latitudinal zones, and for different regional seas. It is common among geochemists and geographers to calculate riverine fluxes per continents (Berner and Berner, 1996; Gerasimov et al., 1964): this type of reporting is used in Table 1. In this table the exorheic catchment area of continents - i.e. the area facing the oceans - includes areas that are not presently characterized by active river runoff - i.e. arheic regions. This operational cut-off is set here at $3 \mathrm{~mm} \mathrm{y}^{-1}$ (Vörösmarty et al., 2000a, b) which corresponds to an average of one flood occurrence every 10 years in desert regions. Presently glaciated areas as Antarctica and major parts of Greenland are not considered in our budget.

Endorheic regions - i.e. facing internal regions - as the Caspian Sea basin (Volga, Terek, Sulak, Kura Rivers), the Rift Valley (Omo River), Lake Chad (Chari and Logone Rivers) and Okawango (Okawango River) basins in Africa, the Lake Eyre Basin (Cooper River) in Australia, the Altiplano (Deseaguadero River) and the Great Basin (Sevier and Humboldt Rivers) in the Americas, the Caspian and Aral Sea basins and other regions of Central Asia, are not considered in our budget although they contribute to the weathering of continents at the global scale. The few major rivers with available data (Meybeck, unpublished report to WHO, Div. Envir. Health, Geneva, "Water quality of endorheic basins", 1996: Chari $19.2 \mathrm{mg} \mathrm{SiO}_{2} \mathrm{l}^{-1}$ for $24.2 \mathrm{~km}^{3} \mathrm{y}^{-1}$ discharge; Logone $19.3 \mathrm{mg} \mathrm{SiO}_{2} \mathrm{l}^{-1}$ for $15.8 \mathrm{~km}^{3} \mathrm{y}^{-1}$, Okawango $16.0 \mathrm{mg} \mathrm{SiO}_{2} \mathrm{l}^{-1}$ for $10.0 \mathrm{~km}^{3} \mathrm{y}^{-1}$; Omo $18.0 \mathrm{mg} \mathrm{SiO}_{2} \mathrm{l}^{-1}$ for $14.0 \mathrm{~km}^{3} \mathrm{y}^{-1}$; Sevier $38.4 \mathrm{mg} \mathrm{SiO}_{2} \mathrm{l}^{-1}$ for $0.02 \mathrm{~km}^{3} \mathrm{y}^{-1}$; Humboldt $32.0 \mathrm{mg} \mathrm{SiO}_{2} \mathrm{1}^{-1}$ for $0.42 \mathrm{~km}^{3} \mathrm{y}^{-1}$ discharge) have a discharge-weighted DSi average of $18.6 \mathrm{mg} \mathrm{SiO}_{2} \mathrm{l}^{-1}$ (1.2 Mt total annual DSi flux for $64.5 \mathrm{~km}^{3}$ of annual discharge, i.e. $7.1 \%$ of the total annual endorheic discharge for $6.1 \%$ of the total endorheic catchment area). Most of these regions are characterised by semi-arid to arid conditions (63\% of the total endorheic area are arheic) with elevated $\mathrm{DSi}$, compared to the global average of the exorheic regions.

The exorheic parts of individual continents are characterized as follows:

Although North America has an average runoff of $268 \mathrm{~mm} \mathrm{y}^{-1}$, much higher than Africa $\left(157 \mathrm{~mm} \mathrm{y}^{-1}\right)$, their silica yields, in $\mathrm{tSiO}_{2} \mathrm{~km}^{-2} \mathrm{y}^{-1}$, are of the same order: $2.2 \mathrm{t} \mathrm{km}^{-2} \mathrm{y}^{-1}$ for North America, $2.0 \mathrm{t} \mathrm{km}^{-2} \mathrm{y}^{-1}$ for Africa. This is in part due to the silica retention by lakes observed in most of the Canadian rivers where the limnic index of lake occurrence is commonly between 5 to $20 \%$ (Meybeck, 1995; Lehner and Döll, 2004): most Canadian rivers have a DSi level between 1.1 and $3.6 \mathrm{mg} \mathrm{SiO}_{2} \mathrm{l}^{-1}$ (see Supplement 1C, COSCATs \#0815 to 0818) while Alaska and British Columbia rivers are characterised by much higher silica levels (COSCATs \#0809, 0810, 0812, 0813) and much lower limnic index (Table 6).

European rivers have the lowest silica levels on average: $5.6 \mathrm{mg} \mathrm{SiO}_{2} \mathrm{l}^{-1}$ vs. $9.5 \mathrm{mg} \mathrm{SiO}_{2} \mathrm{l}^{-1}$ for the global exorheic average. This is probably due to several factors: cold to 
Table 2. Average dissolved and particulate silica fluxes, concentrations (runoff weighted averages) and yields (area weighted averages) from catchments to coastal zones related to ocean basins. Catchment surface area, discharge and runoff are given as well as \% of volcanic rocks from Dürr et al. (2005).

\begin{tabular}{lccccccccc}
\hline & $\begin{array}{c}\text { Catchment } \\
\text { area } 10^{6} \mathrm{~km}^{2}\end{array}$ & $\begin{array}{c}\text { Discharge } \\
\mathrm{km}^{3} \mathrm{y}^{-1}\end{array}$ & $\begin{array}{c}\text { Runoff } \\
\mathrm{mm} \mathrm{y}^{-1}\end{array}$ & $\begin{array}{c}\text { Volcanic rocks } \\
(\mathrm{Vb}+\mathrm{Va}+1 / 2 \mathrm{Cl})^{*} \%\end{array}$ & $\begin{array}{c}\text { DSi mean } \\
\text { concentration } \\
\mathrm{mg} \mathrm{l}^{-1} \mathrm{SiO}_{2}\end{array}$ & $\begin{array}{c}\text { DSi flux } \\
\mathrm{Mty}^{-1} \\
\mathrm{SiO}_{2}\end{array}$ & $\begin{array}{c}\text { DSi yield } \\
\mathrm{tkm}^{-2} \mathrm{y}^{-1} \\
\mathrm{SiO}_{2}\end{array}$ & $\begin{array}{c}\text { PSi flux } \\
\mathrm{M} \mathrm{ty}^{-1} \\
\mathrm{SiO}_{2}\end{array}$ & $\begin{array}{c}\text { PSi yield } \\
\mathrm{km}^{-2} \mathrm{y}^{-1} \\
\mathrm{SiO}_{2}\end{array}$ \\
\hline Arctic & 16.7 & 3310 & 199 & 8.3 & 6.1 & 20 & 1.2 & 122 \\
Atlantic & 57.5 & 19950 & 347 & 5.4 & 8.4 & 169 & 2.9 & 2748 & 47.8 \\
Indian & 20.8 & 5200 & 250 & 7.9 & 12.0 & 62 & 3.0 & 2138 & 102.8 \\
Pacific & 19.8 & 10620 & 1010 & 22.9 & 23.2 & 120 & 6.1 & 3826 & 193.5 \\
Total Exorheic & 114.7 & 39080 & 341 & 9.3 & 9.5 & 371 & 3.3 & 8835 & 77.0 \\
\hline
\end{tabular}

${ }^{*} \mathrm{Vb}-$ Basic volcanic rocks, Va - Acid volcanic rocks, $\mathrm{Cl}$ - Complex lithology (consisting 1/2 of volcanic rocks, see Dürr et al., 2005).

temperate climate, retention of silica in Scandinavian lakes (Conley et al., 2000), scarcity of (young) volcanic rocks and abundance of carbonate rocks (Dürr et al., 2005). Removal of DSi by plankton communities by elevated nutrient ( $\mathrm{N}$ and $\mathrm{P}$ ) levels may impact observed low concentrations, too. Despite our attempt to choose reported DSi concentrations with low anthropogenic impact in general, for Europe it remains difficult to cope with this objective, because of the anthropogenic influence since the 19th century. E.g., Roth (1879) reports nitrate concentration for the Rhine (1848), Seine (1848) and Thames (no date) of 3.8, 14.6 and $3.9 \mathrm{mg} \mathrm{l}^{-1}$, respectively.

Africa silica concentrations are the highest $\left(12.6 \mathrm{mg} \mathrm{l}^{-1}\right.$ on average), despite the scarcity of volcanic rocks. This can be explained by the prevalence of warm climate conditions that favour chemical weathering of crystalline rocks abundant on this continent, for the exorheic regions. In addition, an evaporation effect is likely to influence concentrations (cf. White and Blum, 1995).

South America silica yields are near twice the world average ( $\left.6.1 \mathrm{vs} .3 .3 \mathrm{t} \mathrm{km}^{-2} \mathrm{y}^{-1}\right)$, with silica concentrations very close to the world average ( $9.0 \mathrm{vs.} 9.5 \mathrm{mg} \mathrm{l}^{-1}$ ). This is related to the very high runoff on this continent, $681 \mathrm{~mm} \mathrm{y}^{-1}$ vs. $340 \mathrm{~mm} \mathrm{y}^{-1}$ for the global average: the silica yield of river systems is predominantly controlled by their runoff (Meybeck, 1994). Most of the observed DSi fluxes originate in the humid regions of the Andes (cf. data from different regions of South America in Mortatti and Probst, 2003; Depetris et al., 2005; Jennerjahn et al., 2006), characterised by high proportions of volcanics (Dürr et al., 2005).

DSi fluxes from Asia are not easy to evaluate, because of the great heterogeneity of the continent. The very wet southern flanks of the Himalayan region are characterised by high fluxes due to intensive influence of the monsoon (Kobayashi, 1959), whereas much drier central parts like Tibet are characterised by low fluxes (Galy and France-Lanord, 1999). Large endorheic areas are located in the centre of Asia and cold climate in the northern parts leads to low DSi fluxes.

The silica budgets for ocean drainage basins (Table 2) generate the following comments:
Due to its extended drainage area and water inputs $(50 \%$ of world exorheic), the Atlantic ocean receives $45 \%$ of the silica inputs, with an average concentration $\left(8.4 \mathrm{mg} \mathrm{l}^{-1}\right)$ very close to the world average $\left(9.5 \mathrm{mg}^{-1}\right)$, despite a lower than average outcrop proportion of volcanic rocks (5.4\% vs. $9.3 \%$ on average). The presence of the three world's major rivers in terms of discharge, Amazon (world's first), Congo (second) and Orinoco (third), which are characterised by high runoff values and higher dissolved silica contents $(45.5 \mathrm{M} \mathrm{t}$, $12.4 \mathrm{Mt}$ and $7.2 \mathrm{Mt} \mathrm{SiO}_{2}$ flux per year, carrying alone $18 \%$ of the global exorheic DSi flux), compensates the limited inputs from the dry regions of the Atlantic Ocean basin.

The relatively high dissolved silica concentrations in the Pacific ocean drainage basin rivers $\left(23.2 \mathrm{mg} \mathrm{SiO}_{2} \mathrm{l}^{-1}\right.$ on average) are probably linked to its higher volcanic outcrops (22.9\%) and are thus related to the tectonic activity of the Ring of Fire, surrounding the Pacific. Silica yields in this basin are also the highest, due to a runoff three times the world's average (1010 vs. $340 \mathrm{~mm} \mathrm{y}^{-1}$ ), but its drainage area is relatively small. As a result the absolute DSi flux to the Pacific Ocean is less than the one from the Atlantic drainage basin.

Arctic rivers are characterised by relatively low silica levels, $6.1 \mathrm{mg} \mathrm{SiO}_{2} 1^{-1}$ on average, for an average volcanic rock outcrop. Multiple factors can be invoked: possible lower weathering rates due to colder climate, the extent of permafrost, and the areal proportion of lakes in Canada and Scandinavia, which is an order of magnitude higher than in the other ocean drainage basins (Meybeck, 1995; Lehner and Döll, 2004), resulting from the occurrence of past ice caps in the Arctic drainage basin. The low DSi yield $\left(1.2 \mathrm{t} \mathrm{km}^{-2} \mathrm{y}^{-1}\right.$ vs. the world's average of 3.3) is linked also to a lower runoff $\left(199 \mathrm{~mm} \mathrm{y}^{-1}\right)$. The absolute flux of DSi received by this ocean is only $5.4 \%$ of the world's river fluxes $\left(371 \mathrm{MtSiO}_{2} \mathrm{y}^{-1}\right.$ ).

It is important to note that, when the DSi inputs are compared to ocean volumes and/or to ocean area, these relative inputs are ranked in a very different manner (Table 3 ). Ocean volumes and area are those given by Kossinna (1921) and reported by Viglieri (1966) in Fairbridge (1966). Ocean 
Table 3. Dissolved and particulate silica fluxes received by coastal zones related to ocean basins, rated to coastline length, ocean areas and ocean volumes. Retention of silica in estuaries, on shelves and in regional seas is not considered here. Coastline length, ocean area and ocean volume according to Meybeck et al. $(2006,2007)$.

\begin{tabular}{|c|c|c|c|c|c|}
\hline & Arctic & Atlantic & Indian & Pacific & Global Ocean \\
\hline t DSi silica received per $\mathrm{km} \mathrm{y}^{-1}$ of coastline & 353 & 1133 & 920 & 935 & 923 \\
\hline t per $\mathrm{km}^{2} \mathrm{y}^{-1}$ of ocean area & 1.64 & 1.79 & 0.84 & 0.66 & 1.03 \\
\hline $\mathrm{t}$ per $\mathrm{km}^{3} \mathrm{y}^{-1}$ of ocean volume & 1.47 & 0.50 & 0.22 & 0.17 & 0.28 \\
\hline t PSi received per $\mathrm{km}^{-1}$ of coastline & 2144 & 18541 & 31613 & 29706 & 21992 \\
\hline $\mathrm{t}$ per $\mathrm{km}^{2} \mathrm{y}^{-1}$ of ocean area & 9.97 & 29.3 & 28.9 & 21.1 & 24.4 \\
\hline $\mathrm{t}$ per $\mathrm{km}^{3} \mathrm{y}^{-1}$ of ocean volume & 8.92 & 8.18 & 7.51 & 5.36 & 6.55 \\
\hline
\end{tabular}
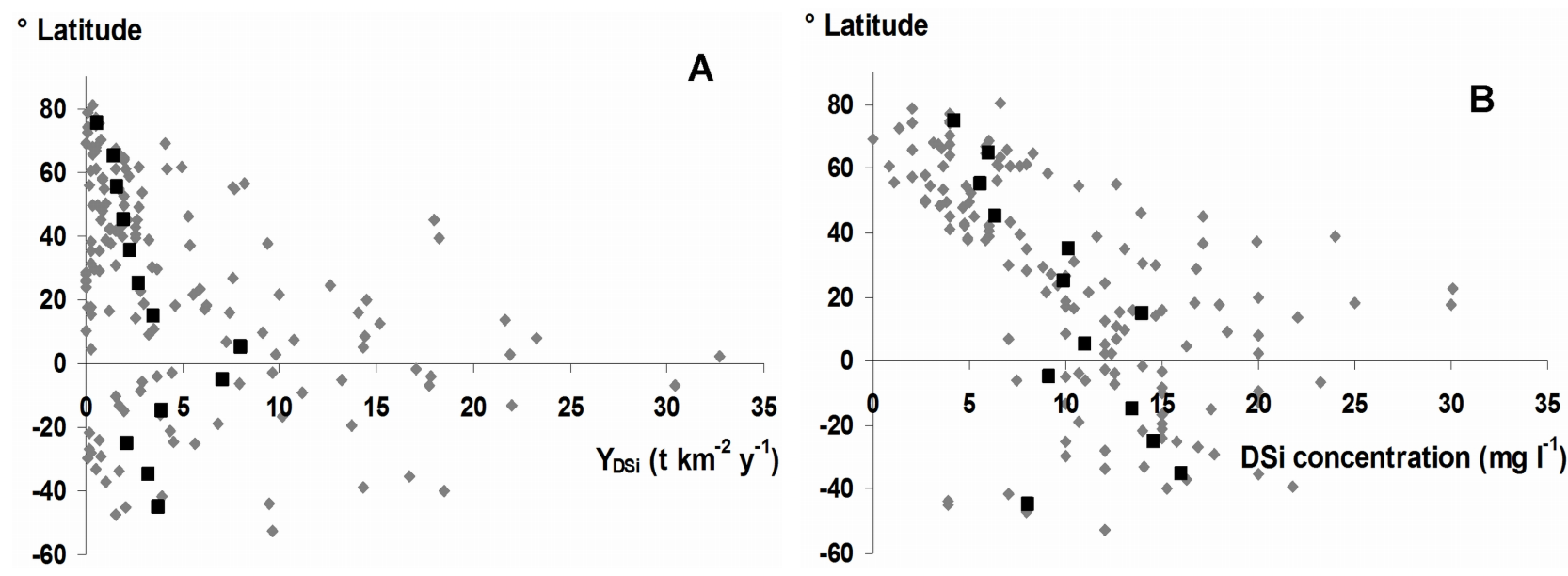

Fig. 2. Latitudinal distribution of dissolved silica inputs to coastal zones (at barycentre of the $140 \mathrm{COSCATs}) .(\mathbf{A}): Y_{\mathrm{DSi}}$ in $\mathrm{tSiO}_{2} \mathrm{~km}^{-2} \mathrm{y}^{-1}$, (B): DSi concentration in $\mathrm{mg} \mathrm{SiO}_{2} 1^{-1}$. Grey dots: individual COSCATs, black dots: averages per $10^{\circ}$ latitudinal bands.

coastline has been determined here for each COSCAT at the $0.5^{\circ} \times 0.5^{\circ}$ resolution (Meybeck et al., 2006) and may be somewhat lower than the actual coastline delineated at a finer resolution: it varies between $57000 \mathrm{~km}$ for the Arctic Ocean and $149000 \mathrm{~km}$ for the Atlantic Ocean (Meybeck et al., 2007). The Arctic Ocean is actually receiving the maximum DSi inputs with regards to its size and the relative silica inputs to the Pacific Ocean are more than one order of magnitude less.

The global estimate for river SPM fluxes to coastal zones is 16 billion tons per year (Ludwig and Probst, 1998), corresponding to a mean concentration of $226 \mathrm{mgl}^{-1}$ or about 9 billion tons of particulate $\mathrm{Si}$, expressed as $\mathrm{SiO}_{2}$, i.e. the $\mathrm{DSi} / \mathrm{PSi}$ ratio at the global scale is $4.2 \%(371 / 8835=0.042)$. As the PSi concentration in SPM is nearly constant $(26 \% \pm$ $4 \%$ of $\mathrm{Si}$ ), the distribution of PSi concentration per liter of water ranges over three orders of magnitude in rivers since it is similar to the one of SPM which commonly varies between less than $10 \mathrm{mgl}^{-1}$ to more than $10000 \mathrm{mgl}^{-1}$ in world rivers. We refer here to the large body of literature describing the characteristics of SPM yields and concentra- tions in world rivers (e.g., Milliman and Syvitski, 1992; Ludwig and Probst, 1998; Meybeck et al., 2003; Syvitski et al., 2005 and references therein).

The latitudinal distribution of the measured and/or estimated DSi from the $\sim 140$ coastal segments is reported on Fig. 2, using the latitude of the COSCAT barycentre (or gravity centre). Maximum concentrations are found in the subtropical regions while the boreal regions have much lower concentrations: minimum concentrations of the sub-tropics (around $10 \mathrm{mg} \mathrm{SiO}_{2} \mathrm{1}^{-1}$ ) are higher than maximum concentrations north of $50^{\circ} \mathrm{N}$ and south of $45^{\circ} \mathrm{S}$. Due to the runoff minimum for the $20-30^{\circ} \mathrm{N}$ and $20-30^{\circ} \mathrm{S}$ belts, the DSi export rate is relatively low at these latitudes despite medium DSi concentrations. The maximum DSi is actually linked to the wet sub-tropics where both high DSi concentrations and runoff are encountered. With few exceptions, regions with high DSi yields correspond to high runoff values as well as high DSi concentrations, but this is a very general picture for all latitudes. For example, most COSCATs with DSi yields $\geq 2 \times$ the world exorheic average, i.e. $\geq 6.6 \mathrm{t} \mathrm{km}^{-2} \mathrm{y}^{-1}$, also have runoff values $\geq 2 \times$ the world exorheic average, i.e. 
Table 4. Percentages of documented area, discharge and corresponding dissolved $\mathrm{SiO}_{2}$ fluxes for continents, regional seas and ocean drainage basins.

\begin{tabular}{lccc}
\hline & $\%$ Area & \% Discharge & \% DSi flux \\
\hline Africa & 46.3 & 46.9 & 43.5 \\
Europe $^{*}$ & 53.0 & 47.0 & 44.3 \\
North America & 60.2 & 51.6 & 49.0 \\
South America & 69.4 & 78.3 & 70.1 \\
Asia & 63.1 & 54.6 & 44.7 \\
Australasia & 25.8 & 25.2 & 25.0 \\
\hline Regional Seas & 53.6 & 48.5 & 42.2 \\
Arctic & 77.3 & 81.6 & 76.8 \\
Atlantic & 59.4 & 68.5 & 66.8 \\
Indian & 36.5 & 41.0 & 35.2 \\
Pacific & 53.0 & 41.4 & 33.1 \\
Total Exorheic & 56.7 & 58.6 & 51.1 \\
\hline
\end{tabular}

* Including a small non-glaciated fraction of Greenland.

$\geq 680 \mathrm{~mm} \mathrm{y}^{-1}$ (see discussion). The relative minimum in silica concentrations around the equator might be due to the often deeply weathered environments in the Brazilian and African shields located in the central tropics (cf. Boeglin and Probst, 1998). For example, the two largest tropical rivers, i.e. the Amazon and Congo, both show relatively low concentrations at their river mouth. They are characterised by large proportions of deeply weathered regolith in areas contributing large proportions of runoff and, in the case of the Congo river, also some proportions of carbonates are present (Probst et al., 1994; Stallard, 1995; Mortatti and Probst, 2003; Dürr et al., 2005). Low concentrations can further be attributed to tectonic stability $(\gg 100 \mathrm{My})$ and to the high precipitation in these wet tropical regions (cf. Stallard, 1995; Mortatti and Probst, 2003). The northern Hemisphere is characterised by a strong latitudinal correlation of DSi concentrations and yields towards the equator and is probably indicating the influence of temperature and vegetation, pointed out by missing values in the lower concentration range in the subtropical and tropical zone.

\section{Discussion}

\subsection{Global coverages and approaches to river silica budgets}

For each coastal catchment we have determined the sum of documented silica fluxes vs. undocumented ones and their related areas and runoff. These area and discharge coverage rates are tabulated for individual continents and ocean drainage basins on Table 4, and in the Supplement for individual COSCATs. The resulting percentages of dissolved silica flux coverage range from $25 \%$ for Australasia - i.e. Aus- tralia, New Guinea and New Zealand - to $81 \%$ for the Arctic river runoff. The mean coverage rates are $56.7 \%$ for the continental area, $58.6 \%$ for the continental runoff, and $51 \%$ for the silica flux, i.e. half of the silica flux is based on actual water analyses combined with measured runoff, half has been extrapolated. This extrapolation has been realized by the product of estimated regional or local DSi concentrations and the river runoff over undocumented areas, now known from global models with a satisfactory accuracy (Fekete et al., 2002). If we assume that DSi analytical uncertainties and flux calculation uncertainties for documented rivers are negligible, the uncertainty induced by the frequency of regular river measuring campaigns results in errors around $10 \%$ for major ions as expressed by the electrical conductivity (Moatar and Meybeck, 2007), and is likely to be identical for DSi. Based on extrapolation studies for dissolved silica fluxes (Hartmann et al., 2010a; Jansen et al., 2010; Moosdorf et al., 2010), it can be assumed that the performance of the budget approach is weaker. The maximum uncertainty will thus be somewhat higher: sometimes not many analyses are used for a certain value or no measurements over several seasons exist, or only arithmetic averages are available instead of discharge-weighted averages. While it is difficult to put actual numbers on the overall uncertainties, considering available data and that the budget approach was designed to overcome gaps of data for certain local and regional areas, some aspects are better known, such as the uncertainty induced by extrapolating annual averages of concentrations (cf. Moatar and Meybeck, 2007). As a rough approximation, we estimate that the additional uncertainty on extrapolated yields, using our method, yields in a total error probably not much greater than $30 \%$ for the regional scale. Locally, and in less well documented areas, the uncertainty is of course higher. However, as the budget approach closes gaps in knowledge of DSi-concentrations from certain areas, a reliable and calculable number can not be provided for these areas.

The silica content of river SPM also depends on the grain size: coarser bed sediments are more siliceous with contents around $300000 \mathrm{ppm}$ while SPM is mostly in the silt and clay fraction and has a lesser quartz content and a higher content in $\mathrm{Al}$, and therefore a lower content of $\mathrm{Si}$. Viers et al. (2009) found low carbonate contents, also with very little variation. The stream bed sediments in European rivers are around 286000 while river alluvial deposits are at 302000 ppm (median values, De Vos et al., 1996; Salminen et al., 2005; De Vos et al., 2006). The hypothesis of constant PSi content in river particulates induces thus an uncertainty of $\pm 15 \%$ on average and probably lower than the uncertainty of particulate matter fluxes. The total PSi flux of rivers depends on their suspended particulate budget. The inputs of PSi to oceans thus greatly depend on the estimates of SPM fluxes by rivers. Ludwig and Probst's (1998) estimate might underestimate some inputs, especially from the smallest basins (basin area $<10000 \mathrm{~km}^{2}$ ), particularly in South 
Table 5. Existing global budgets and values of ranges for dissolved silica (DSi).

\begin{tabular}{|c|c|c|}
\hline Reference & $\begin{array}{c}\text { Global average } \\
\text { concentration } \\
\left(\mathrm{mg} \mathrm{l}^{-1} \mathrm{SiO}_{2}\right)\end{array}$ & Approach \\
\hline Clarke (1924) & 8.3 & $\begin{array}{l}\text { Extrapolated from few, } \\
\text { big temperate rivers }\end{array}$ \\
\hline Livingstone (1963) & 13.1 & As Clarke (1924) \\
\hline Meybeck (1979) & 10.4 & $\begin{array}{l}\text { Biomes typology, } \\
60 \text { rivers, } \\
\text { Amazon included }\end{array}$ \\
\hline Probst (1992) & 8.9 & $\begin{array}{l}\text { Multiregression } \\
\text { (Meybeck's data) }\end{array}$ \\
\hline Meybeck (1992, unpublished) & 9.2 & $\begin{array}{l}\text { Data later published as } \\
\text { Meybeck and Ragu (1995); } \\
\text { plus } 9 \text { morphotectonic } \\
\text { types (lithological control) }\end{array}$ \\
\hline Tréguer et al. (1995) & 9.1 & $\begin{array}{l}\text { Meybeck and Ragu (1995) } \\
\text { data }\end{array}$ \\
\hline Meybeck (2003) & 8.75 & $\begin{array}{l}\text { On the totality of the } \\
\text { analyses from Meybeck and } \\
\text { Ragu (1995) ( } 260 \text { rivers } \\
\text { and tributaries, } \\
\text { exo- and endorheic) }\end{array}$ \\
\hline Beusen et al. (2009) & 9.7 & $\begin{array}{l}\text { Same data as here, multiple } \\
\text { linear regression model }\end{array}$ \\
\hline
\end{tabular}

East Asia coasts (Milliman and Syvitski, 1992). Recent models give varying numbers (Vörösmarty et al., 2003; Syvitski et al., 2005 and references therein), due to the balance between enhanced inputs owing to land use changes on the one hand, and to enhanced retention by reservoirs on the other (see discussion in Vörösmarty and Meybeck, 2004).

As for any global river budget, it is very much dependant on the analyses of the largest rivers, i.e. Amazon, Congo, Orinoco, Ganges and Brahmaputra, Mississippi, Yangtze, and Great Arctic rivers which are surveyed by water quality authorities and/or by scientists. An error on the Amazon average concentration (15\% of the world river discharge) may affect the whole budget. The use of a complex model linking all control factors to silica yields as developed by Probst (1992) or more recently - using the data presented here - by Beusen et al. (2009) for DSi, would not have improved much our mode of extrapolation, since previous multi-regression models are globally not more accurate than $30 \%$. Compare for results of global land-ocean flux estimations of carbon and nutrients and individual discussions (Global Biogeochemical Cycles special issue on Global Nutrient Fluxes from Watersheds (Global-NEWS), edited by Seitzinger et al., 2005; individual discussions are provided on sediment fluxes by Beusen et al. (2005) on nitrogen by Dumont et al., 2005, and on phosphorus by Harrison et al., 2005).

When comparing global average silica concentrations that have been proposed since Clarke's first estimate in 1924, these figures have not changed much: they range between 8.3 and $13.1 \mathrm{mg} \mathrm{l}^{-1} \mathrm{SiO}_{2}$ (Table 5). Clarke's figure $\left(8.3 \mathrm{mg} \mathrm{l}^{-1} \mathrm{SiO}_{2}\right)$ was an arithmetic average based on the silica content of dry residue from few major rivers, mostly located in the North temperate regions of Europe and North America. Livingstone made first an arithmetic average of DSi for each continent, then these means were weighted by the average runoff of the continents (six continents including Australia) in order to calculate the "global weighted DSi". He obtained a higher value $\left(13.1 \mathrm{mg}^{-1} \mathrm{SiO}_{2}\right)$. Since continents are generally heterogeneous, this approach is not very reliable (e.g., Asia average of $11.7 \mathrm{mg} \mathrm{l}^{-1} \mathrm{SiO}_{2}$, mostly based on tropical Asia since Livingstone's data set does not contain any Russian rivers). The first average made by Meybeck in $1979\left(\mathrm{DSi}=10.4 \mathrm{mg} \mathrm{l}^{-1} \mathrm{SiO}_{2}\right.$ ) was based on 60 rivers distributed in most continents with less weight from the big Arctic rivers, and developed for the first time a simple typology linking silica yields with temperature and runoff to 
extrapolate the documented data set to unknown regions. The first multi-regression approach was made by Probst in 1992 on the same set of rivers, mostly large ones. It resulted in a $8.9 \mathrm{mg} \mathrm{l}^{-1} \mathrm{SiO}_{2}$ average, very close to the present average. A previous unpublished attempt for global silica budgets has been made by one of our co-authors (M. Meybeck, unpublished data, 1992) on the basis of a new and larger data set $(n=250)$, later published as the GEMS-GLORI register (Meybeck and Ragu, 1995). It was based on another typology, based on tectonics and global geomorphology: 9 morpho-tectonic types were defined, such as old and recent sedimentary basins, Hercynian, Caledonian and Alpine mountain ranges, active volcanism etc. The corresponding silica average by this approach was $9.2 \mathrm{mgl}^{-1} \mathrm{SiO}_{2}$. A similar level $\left(9.1 \mathrm{mg} \mathrm{l}^{-1} \mathrm{SiO}_{2}\right)$ has been reached by Tréguer et al. (1995) on the basis of the GEMS-GLORI data that was communicated to these authors. The exorheic plus endorheic rivers have also been considered recently (Meybeck, 2003, see also the Supplement), also using exorheic rivers selected by Meybeck and Ragu (1995) plus major endorheic rivers, the corresponding world weighted average is $8.7 \mathrm{mg} \mathrm{l}^{-1} \mathrm{SiO}_{2}$.

Recently, and partly also based on the data compiled here, the major control factors on local, regional and global DSi fluxes have been analysed using empirical techniques. Control factors are usually extracted by using small to medium sized catchments $\left(<10000 \mathrm{~km}^{2}\right)$. Some of the controlling factors, including runoff or precipitation, temperature, relief and lithology, have been identified for specific regions of the globe (e.g., Bluth and Kump, 1994; Hartmann et al., 2010a, for Japan; Jansen et al., 2010 for the USA), as well as globally (Beusen et al., 2009). Runoff/precipitation and lithology were identified in most regional to global scale studies as strong predictors for DSi fluxes. However, it remains difficult to disentangle the strength of further effects at the regional to global scale such as vegetation, temperature or relief from the strong influence of lithology and runoff. For example, while correlations of DSi concentrations (not fluxes) with temperature have been observed for certain data (Garnier et al., 2006), the influence of temperature was not always identified in large-scale statistical models (cf., Beusen et al., 2009; Hartmann et al., 2010a). There is thus still a discussion on how and to what extent this assumed temperature effect can be identified, its strength on DSi mobilization can be estimated robustly, and how it could be employed in regional and global scale models (cf. discussions in Godderis et al., 2009; Hartmann and Moosdorf, 2010; Hartmann et al., 2010a).

Comparing the recent literature, it becomes clear that the findings about controlling factors from smaller catchments are not all representative for large basins or the total global DSi budget. The findings of the recent studies confirm in general our results for the global scale. It should be mentioned that there is still an absence of entirely process-based models for the global scale due to difficulties to globalize or regionalize important parameters (cf. Sferratore et al., 2005). We believe that the budget approach presented here, considering local and regional characteristics, is an appropriate tool for deriving a global spatial representation of land-ocean flux estimates. This is supported by the outcomes of the work of Beusen et al. (2009) on DSi, if compared with the results presented here.

It must be reminded that riverine budgets should either associate concentrations and discharges, or yields and area. Extrapolations are then carried out based on the hypothesis of constant concentration or of constant yields. The first hypothesis therefore greatly depends on the global water budget, which is now more and more addressed (Oki et al., 2001; Fekete et al., 2002) and has therefore been chosen here. Although the second one is easier to use, as drainage areas are well defined (e.g. in Meybeck's budget, 1979), it greatly depends on the sample of documented rivers, which should have representative average runoff, sediment yields and lithology (for a more detailed discussion see Meybeck, 1988).

\subsection{Relations between dissolved and particulate silica exports and yields}

Silica yields $Y_{\mathrm{DSi}}$ and $Y_{\mathrm{PSi}}$, expressed in $\mathrm{tSiO}_{2} \mathrm{~km}^{-2} \mathrm{y}^{-1}$, are calculated at the river mouths upstream of the land-ocean interface. Actually, there can be differences between whole river yields at mouth and those measured in headwaters, if retention processes of river-borne material are significant, as for particulates (Walling, 1983; Walling and Webb, 1996), organic carbon (Stallard, 1998), and nutrients, including dissolved silica, which can be processed and stored within the aquatic system (Sferratore et al., 2005).

Long-term average dissolved silica mobilized into river systems ultimately origins from silicate mineral weathering, while particulate Si mostly concerns quartz and clay mineral particles 10 to 50 times less soluble than silicates. The ratio DSi (in $\mathrm{mg}^{-1}$ ) to PSi (in ppm) is thus essentially regulated by grain size and not the weatherability of silicates, as they are rarely dominant on quartz and clay minerals in rivers (if this is the case the resulting rocks are arkoses). The ratio of DSi flux to PSi flux is very low as soon as the SPM fluxes increase (ex. Madeira) and much higher when SPM fluxes are low.

The ratio between average $Y_{\mathrm{DSi}}$ and $Y_{\mathrm{PSi}}$ in COSCATs (Fig. 3) varies over more than three orders of magnitude, from 0.005 to 10 . DSi export nearly matches PSi exports in few regions as in the Zaire-Congo river basin (COSCAT \#0014) and in some Siberian COSCATs, due to the very limited river transport of particulates in downstream areas of these regions.

PSi export largely dominates in most regions and the $Y_{\mathrm{PSi}} / Y_{\mathrm{DSi}}$ can exceed 1000 for the Pohai Gulf (COSCAT \#1325), which is dominated by the HuangHe (Yellow River) sediment inputs. Such an anomaly in the dissolved vs. 


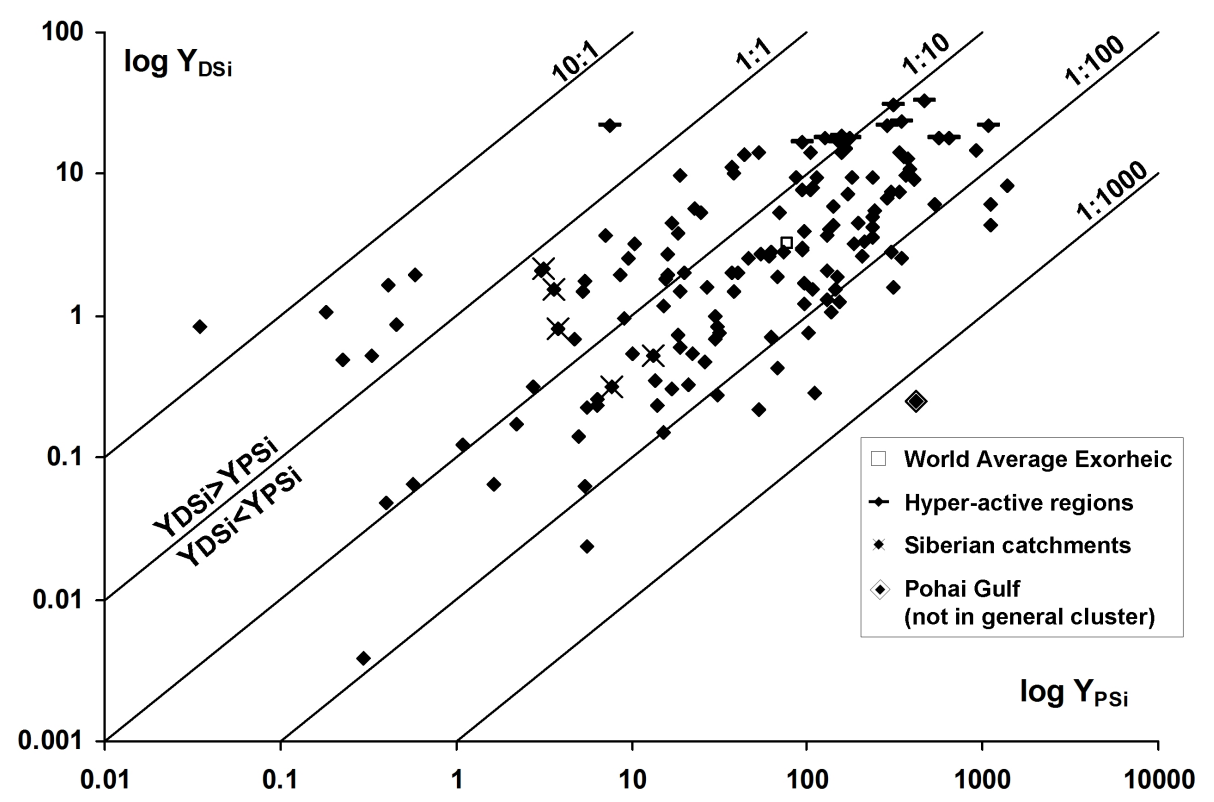

Fig. 3. General relation between dissolved $\left(Y_{\mathrm{DSi}}\right)$ and particulate $\left(Y_{\mathrm{PSi}}\right)$ silica yields in the 140 coastal catchments and in the global budget. $Y_{\mathrm{DSi}}$ and $Y_{\mathrm{PSi}}$ in $\mathrm{t} \mathrm{SiO}_{2} \mathrm{~km}^{-2} \mathrm{y}^{-1}, \log$ scales.

particulate river material relationship has also been observed for the organic carbon (Meybeck, 1993). This observation is attributed to high physical erosion rates from the loess regions within the catchment. The observed weak positive relation between DSi and PSi yields $\left(r^{2}=0.41\right.$ for the $\sim 140 \log$ $\log$ COSCAT couples) is partly due to their common control factor, runoff.

The general positive relationship between dissolved and particulate Si fluxes (Fig. 3) is in accordance with observed correlations between chemical weathering rates and physical erosion for certain regions or geological settings (Gaillardet et al., 1999; Riebe et al., 2001; Millot et al., 2002; Lyons et al., 2005; West et al., 2005). However, in specific regions of the world opposite trends have been found as for the USA (see a complete discussion in Meybeck, 1994).

The world weighted average DSi/PSi ratio in COSCATs of $4.2 \%$ (median $4.0 \%$ ) is slightly biased towards the particulate material. Regions in which the dissolved silica export is dominant ( $\mathrm{DSi}>\mathrm{PSi}$ ) are very rare and correspond essentially to Hudson Bay drainage, i.e. to lake outlets where PSi is completely trapped (also $Y_{\mathrm{PSi}}$ is not measured in those areas, but estimated from the Ludwig and Probst (1998) model with many uncertainties in those lake-covered regions). In these environments PSi at lake outlets may be largely biogenic (diatoms).

\subsection{Hot spots of river silica inputs to coastal zones}

Export rates of silica by rivers vary over more than 3 orders of magnitude for particulates and 2 to 3 orders for the dissolved component (Fig. 3). After yields normalisation to the world average, the relative rates, scaled to the world's weighted average, $Y_{\mathrm{DSi}} / \overline{Y_{\mathrm{DSi}}}$, can be compared for any type of river material. Meybeck et al. (2006) have proposed a general classification of relative rates in 7 classes, centred around the world average $\left(\overline{Y_{\mathrm{DSi}}}\right)$ :

- Hot regions have $10<Y_{i} / \overline{Y_{i}}$

- Hyper-active regions are characterised by $5<Y_{i} / \overline{Y_{i}}<10$ (see Fig. 3)

- Eury-active regions by $2<Y_{i} / \overline{Y_{i}}<5$

- Meso-active regions by $0.5<Y_{i} / \overline{Y_{i}}<2$

- Hypo-active regions by $0.2<Y_{i} / \overline{Y_{i}}<0.5$

- Oligo-active regions by $0.1<Y_{i} / \overline{Y_{i}}<0.2$

- Steno-active regions by $0.01<Y_{i} / \overline{Y_{i}}<0.1$

- Inactive regions have $Y_{i} / \overline{Y_{i}}<0.01$

For dissolved silica, at the spatial resolution of COSCATs, i.e. circa one million $\mathrm{km}^{2}$, there are no true hot spots, but several hyper-active regions are found, as in humid tropical regions and/or wet volcanic regions (Fig. 4). Of particular interest is the Pacific Ocean drainage basin where most hyperactive COSCATs are found: they coincide with the dominance of volcanic outcrops related to the Pacific Ring of Fire from Kamchatka to Java, in Central America, and in the wet coast of South Chile.

In contrast, most of the northern COSCATs are hypoto steno-active (e.g. West Hudson Bay). The Amazon and 


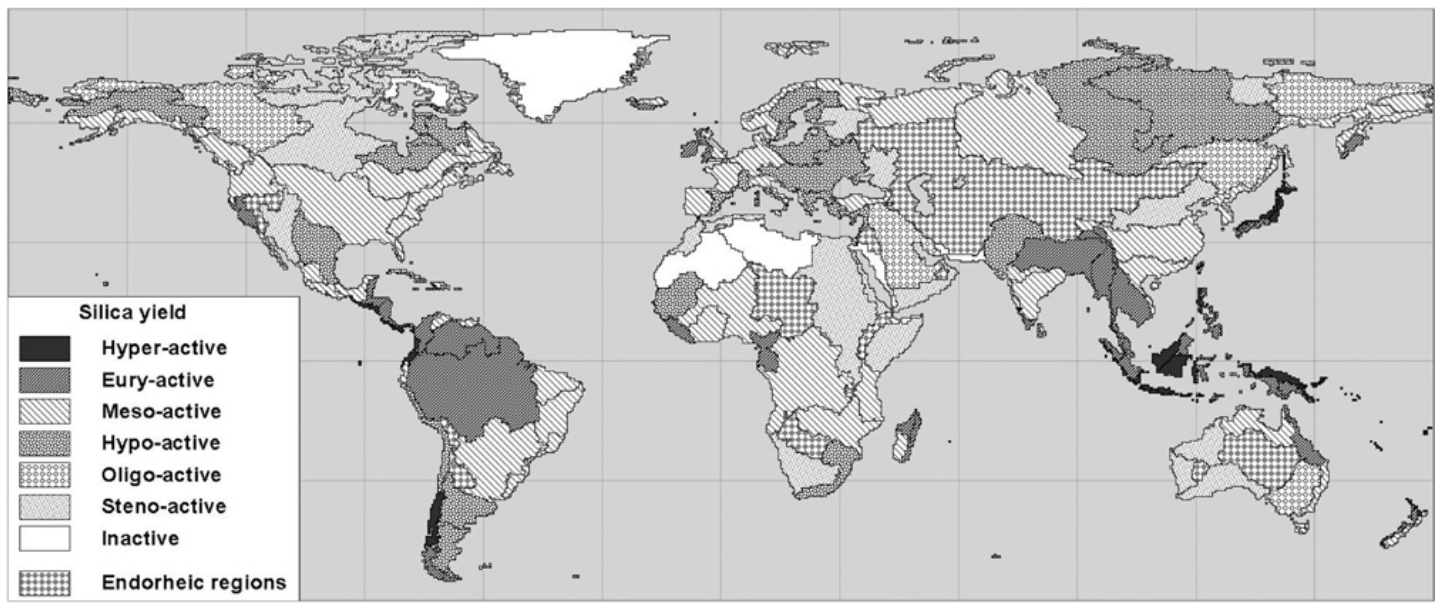

Fig. 4. Relative natural dissolved silica yield for coastal catchments (COSCATs) (115 $\mathrm{Mkm}^{2}, n \approx 140$, global mean yield $3.3 \mathrm{t} \mathrm{DSi} \mathrm{km}{ }^{-2} \mathrm{yr}^{-1}$ ). Inactive areas $0-0.01 \times$ global mean yield, steno-active $0.01-0.1 \mathrm{x}$, oligo-active $0.1-0.2 \mathrm{x}$, hypo-active $0.2-0.5 \mathrm{x}$, mesoactive $0.5-2 x$, eury-active 2-5x, hyper-active 5-10x. No Hot spots ( $>10 \times$ global mean yield) are observed at this scale. Silica yield classes boundaries see also Fig. 5. Antarctica and glaciated parts of Greenland not considered. Endorheic regions are set apart.

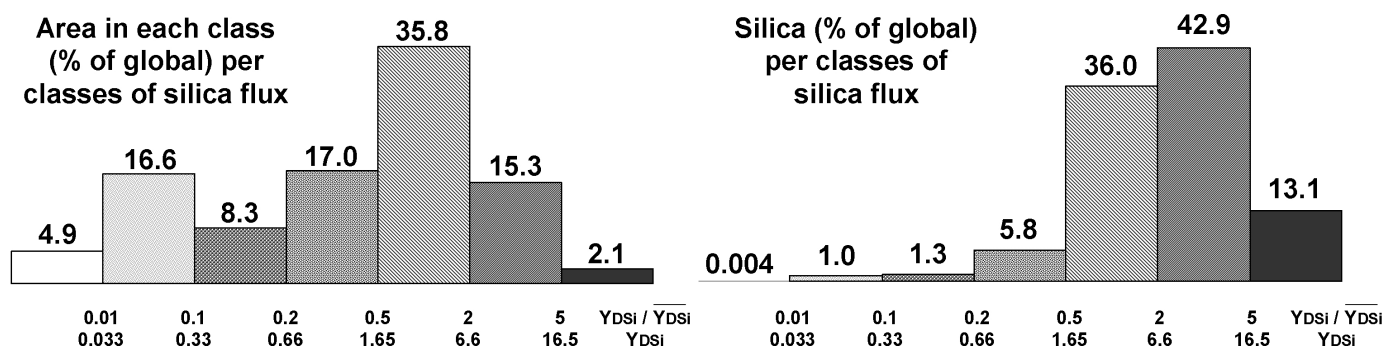

Fig. 5. Relative distribution of dissolved silica yields in exorheic basins $\left(115 \mathrm{M} \mathrm{km}^{2}, n \approx 140\right)$. Classes are constructed after the mean yield of $3.3 \mathrm{tDSi} \mathrm{km}^{-2} \mathrm{yr}^{-1}$ (see text). Antarctica and glaciated parts of Greenland not considered.

Orinoco regions and the Asian monsoon regions, from the Ganges to the Mekong, are eury-active, i.e. between 2 and 5 times the world average DSi yields. Maximum dissolved silica yields are found in subtropical and tropical, as well as in wet volcanic regions (Jennerjahn et al., 2006; Hartmann et al., 2010a). For example, the yield of the Japanese river Tokachi, included in the database, is $37 \mathrm{tSiO}_{2} \mathrm{~km}^{-2} \mathrm{y}^{-1}$ $\left(\mathrm{DSi}=29.9 \mathrm{mg} \mathrm{SiO}_{2} \mathrm{l}^{-1}\right.$, runoff $q=1240 \mathrm{~mm} \mathrm{y}^{-1}$, catchment area $8800 \mathrm{~km}^{2}$ ) (Kobayashi, 1960). As silica concentrations are even higher in volcanic and hydrothermal regions as in Kamchatka (e.g., $41.9 \mathrm{mg}^{-1} \mathrm{SiO}_{2}$ for a spring close to Koryaksky volcano; Hartmann, 2006), and fresh unweathered ashes are capable to release large amounts of DSi, high $Y_{\mathrm{DSi}}$, exceeding $50 \mathrm{t} \mathrm{km}^{-2} \mathrm{y}^{-1}$, are possible at the local scale (Hartmann et al., 2010a). Other hot spots of silica fluxes combine extreme runoff and active tectonics as for the $\mathrm{Pu}$ rari river (New Guinea) which exports $35.2 \mathrm{t} \mathrm{SiO}_{2} \mathrm{~km}^{-2} \mathrm{y}^{-1}$ (DSi $=13.8 \mathrm{mg} \mathrm{SiO}_{2} \mathrm{l}^{-1}$ and $q=2750 \mathrm{mmy}^{-1}$, data from Petr, 1983, see also Supplement 1F).

A similar mapping as for DSi can be made for PSi. If the particulate Si content in river SPM could be considered as constant $( \pm 26 \mathrm{wt} \%)$ for the regional scale, the pattern of PSi yield is identical to the one observed for SPM fluxes from models, which show that most land-ocean fluxes originate from the erosion of the Himalayas, South East Asia island arcs and archipelagos, from Taiwan to New Zealand (Milliman and Syvitski, 1992; Ludwig and Probst, 1998). Note that we have not focused on spatial BSi distribution here, because the bioavailable part of PSi $(=\mathrm{BSi})$ is actually still under discussion, without a definitive emerging number and we found that the few available studies providing local data do not provide a large enough data base for an appropriate global spatialization (cf. Conley, 1997).

When the global silica budget is disaggregated for the 7 relative flux classes, from inactive to hyper-active regions (Fig. 5), the following observations can be made:

- $17.4 \%$ of the exorheic area contribute to $55 \%$ of the dissolved silica fluxes (eury- to hyper-active regions).

- $28.9 \%$ of the exorheic area contribute to only $2.3 \%$ of fluxes (inactive, steno- and oligo-active regions). 
This skewed distribution of riverine fluxes is very general and has been observed for water, suspended matter and nutrients as total nitrogen (Meybeck et al., 2006).

\subsection{Towards spatial estimates of net river inputs to oceans}

At the beginning of global bio- and geochemical cycles studies, significantly influenced by the work of Mackenzie and Garrels (Mackenzie and Garrels, 1966; Garrels et al., 1973), the amount of data on world rivers was scarce, GIS did not exist nor global models. Therefore it was difficult to spatialize river inputs at global scale. The global budget of silica (Tréguer et al., 1995) was also not spatialized. The first major improvement was the use of GIS and multi-regressions to build up spatialized models of river inputs to oceans at the basin scale (Probst, 1992; Ludwig et al., 1996; AmiotteSuchet et al., 2003; Beusen et al., 2009). These river material budgets were then used in regional ocean biogeochemical models as for organic carbon (Aumont et al., 2001). However, they did not take into account the natural filters between river basins and the open ocean as estuaries, shelves and regional seas (Meybeck and Dürr, 2009).

The processing and retention of dissolved silica in estuaries and its potential impact on coastal food webs has been demonstrated since several decades (Nixon, 1987; Billen and Garnier, 1997; Rabalais and Turner, 2001). The retention of riverine silica and other nutrients on the shelf is also well documented (DeMaster et al., 1983; Rabouille et al., 2001; Dagg et al., 2004). However, none of these processes have been addressed at the global scale.

The main transformations occurring to silica in near-shore and estuarine environments are (i) its uptake by silicifying organisms such as diatoms under its dissolved form to produce biogenic silica (Roubeix et al., 2007 and references therein), (ii) the dissolution of the particulate pool within the water column or the upper layer of the sediment which regenerates dissolved silica (Yamada and D'Elia, 1984) and (iii) the permanent storage of the particulate silica through sediment accumulation which constitutes the sink term of the system and leads to long-term Si retention (Nixon, 1987). The importance of a proper representation of the particulate biogenic pool of silica was pointed out by several authors (Conley, 2002 and references therein). The fraction of PSi that is considered possibly dissolvable and biologically available is currently not well known. Most of the PSi is in mineral form that will dissolve only very slowly and mainly be buried and re-mineralized in marine sediments. A small fraction of PSi is constituted of biological material (i.e., BSi), mostly phytoliths and diatom frustules. This BSi is considered orders of magnitude more easily soluble than the remainder of PSi, i.e. it can become bioavailable, and can thus contribute to algal growth (van Cappellen, 2003). The BSi fraction in PSi is difficult to estimate as it depends very much on the river basin considered and will be linked to control factors such as forest distribution, land use, water turbidity, or any factor likely to influence diatom productivity. Conley (1997) estimated the global BSi load to estuaries at $63 \pm 7.2 \mathrm{MtSiO}_{2} \mathrm{y}^{-1}\left(1.05 \pm 0.2 \mathrm{Tmol} \mathrm{Si} \mathrm{y}^{-1}\right)$, i.e. $17 \%$ of the total DSi flux. This represents just $0.75 \%$ of the total PSi export from the rivers, and, considering the lithogenic fraction of the PSi as biologically inert, the available fraction might thus be $<1 \%$ (see Table 1), due to the overwhelming mineral composition of PSi. This fraction can be seen as the maximum amount of PSi potentially recycled and biologically available at shorter timescales and is 5 to 6 times smaller than the pool of DSi.

However, direct measurements of BSi fluxes in budgets are still scarce and, for instance, BSi production in coastal environments is often deduced from primary production or DSi consumption (Beucher, 2003). Estimates of the net uptake of silica in estuaries deduced from estuarine mixing curves, i.e. DSi vs. salinity relationship from rivers to sea waters, are still the most common type of studies available in the literature and both excess and depletion patterns of DSi in estuarine environments have been observed, they vary seasonally and between stations. Net budgets to oceans, combining silica patterns and river discharges are very limited and/or biased (for example, summer profiles are much more common than profiles at river flood stage) (DeMaster, 1981; Aston, 1983; Balls, 1994; Rendell et al., 1997; Kimmerer, 2005; Chou and Wollast, 2006). However, primary production is a typically seasonal process driven by light and temperature conditions and varies greatly through the year as do river inputs. Hence, extrapolating an annual flux from these estimates is a difficult task which also does not account for the potential transient storage within the estuary itself (Webster et al., 2000). Moreover, the net uptake is a transfer from the dissolved to the particulate pool but does not indicate the real retention of silica within the system. For that matter, the work of DeMaster (2002) to quantify the accumulation of particulate silica within the sediment remains one of the only references at global scale but is essentially based on carbon measurements and molecular ratios. Recent studies also indicate that this retention can be influenced by "reverse weathering", a process suggested by Mackenzie and Garrels (1966), and describing formation of new aluminosilicate minerals from $\mathrm{BSi}$ in marine sediment by chemical combination of elemental material from oceans and marine sediments (Mackenzie and Kump, 1995; Michalopoulos and Aller, 1995; Michalopoulos et al., 2000). The quantity that is removed by reverse weathering reactions is assumed to be a small fraction of the total river input, but is currently not precisely known (Holland, 2005). Results for the Amazon delta suggest that 90\% of the biogenic silica originally present in deposits is converted to clay or otherwise altered and the deltaic storage of riverine $\mathrm{Si}$ is estimated to be $\sim 22 \%$ of the Amazon River input (Michalopoulos and Aller, 2004). Further retention may result from the activity of benthic organisms that enhance benthic-pelagic coupling (Ragueneau et al., 2005) but large 
Table 6. Dissolved silica fluxes, concentration and yield for selected regional sea catchments: North Atlantic Regional Seas and Japan Sea. Catchment surface area, discharge and runoff are given from Meybeck et al. (2007) as well as \% of volcanic rocks from Dürr et al. (2005) and lake density from Lehner and Döll (2004).

\begin{tabular}{|c|c|c|c|c|c|c|c|c|}
\hline & $\begin{array}{l}\text { Catchment } \\
\text { area } 10^{6} \mathrm{~km}^{2}\end{array}$ & $\begin{array}{l}\text { Discharge } \\
\mathrm{km}^{3} \mathrm{y}^{-1}\end{array}$ & $\begin{array}{l}\text { Runoff } \\
\mathrm{mm} \mathrm{y}^{-1}\end{array}$ & $\begin{array}{l}\text { Lake density } \\
\%\end{array}$ & $\begin{array}{l}\text { Volcanic rocks } \\
(\mathrm{Vb}+\mathrm{Va}+1 / 2 \mathrm{Cl}) \%\end{array}$ & $\begin{array}{l}\mathrm{SiO}_{2} \text { flux } \\
\mathrm{Mty}^{-1}\end{array}$ & $\begin{array}{l}\mathrm{SiO}_{2} \text { mean } \\
\text { concentration } \\
\mathrm{mg} \mathrm{l}^{-1}\end{array}$ & $\begin{array}{l}\mathrm{SiO}_{2} \text { yield } \\
\mathrm{t} \mathrm{km}^{-2} \mathrm{y}^{-1}\end{array}$ \\
\hline Baltic Sea & 1.6 & 390 & 240 & 6.4 & 2.8 & 1.5 & 3.9 & 0.9 \\
\hline $\begin{array}{l}\text { Black Sea } \\
\text { (incl. Azov) }\end{array}$ & 2.4 & 410 & 170 & 0.78 & 8.7 & 2.1 & 5.1 & 0.9 \\
\hline Mediterranean Sea & 8.3 & 800 & 97 & 1.3 & 6.0 & 3.3 & 4.1 & 0.4 \\
\hline Hudson Bay & 4.0 & 850 & 210 & 10.5 & 2.4 & 1.7 & 1.9 & 0.4 \\
\hline St. Lawrence Gulf & 1.6 & 630 & 402 & 19.4 & 2.4 & 3.3 & 5.2 & 2.1 \\
\hline $\begin{array}{l}\text { N. American Med. Seas } \\
\text { (Gulf of Mexico, Caribbean) }\end{array}$ & 6.5 & 1875 & 290 & 0.95 & 6.9 & 22.7 & 12.1 & 3.5 \\
\hline Japan Sea & 0.4 & 240 & 580 & - & 39.2 & 4.1 & 17.1 & 9.9 \\
\hline
\end{tabular}

scale extrapolations remain to be calculated. One may also refer to the concept of proximal and distal limited filters for the coastal ocean (Rabouille et al., 2001).

Overall, this relative lack of specific data, combined with the heterogeneity of the coastal zone and the question of its precise definition (Smith and Hollibaugh, 1993), makes the quantification of global budgets a very difficult task and stresses out the need for a coastal typology of coastal systems especially for small to medium-sized systems. The world's largest rivers, however, often generate large plumes which consist in an "external" estuary dominating the biogeochemical transformations occurring in the adjacent continental shelf. Therefore, a good understanding of these Riverdominated Ocean Margin (RiOMar, McKee, 2003) systems and their plumes would help significantly understanding and quantifying the fate of silica in the coastal zone (Johnson et al., 2006). Differences between estuarine systems where the major processing occurs near-shore and large systems such as the Amazon (DeMaster et al., 1983; Michalopoulos and Aller, 2004), the Zaire/Congo with its submarine canyon (Chou and Wollast, 2006), the Mississippi (Rabalais and Turner, 2001) or the Danube delta (Ragueneau et al., 2002), should be regarded with greatest attention (Liu et al., 2010).

It remains thus very difficult to quantify these processes and resulting fluxes at the global scale, considering the number of transformations involving silica that can potentially occur in estuaries, river plumes or shelf areas. To our knowledge, only one other study has summarised the existing knowledge of the global silica cycle for the various silica pools and transformation processes (Laruelle et al., 2009).

In addition to the silica transformation and retention processes in the coastal zone, one should also consider the retention in major regional seas of the world. They have been considered as mega filters within an Earth System analysis (Meybeck et al., 2007; Meybeck and Dürr, 2009). Five types of mega filters have been defined: three types of regional seas, depending on their connection to the open ocean, plus extended platforms (e.g. Siberian seas) and coastal archipelagos (e.g. Canadian Archipelago and South Chile Coast). Their related drainage area and riverine fluxes have been tabulated using a specific re-aggregation of the COSCATs mega puzzle. On the basis of simple assumptions relating the retention of particulates to the morphology of these mega filters and the retention of nutrients to their theoretical river water residence time, which exceeds three orders of magnitude between the Saint Lawrence Gulf (fastest renewal) and the Red Sea (longest renewal), it has been estimated that (Meybeck et al., 2007):

i. Regional seas intercept $39 \%$ of the exorheic continental landmass (glaciated areas as most of Greenland and Antarctica excluded), and $35 \%$ of the exorheic river runoff.

ii. Regional seas store about $80 \%$ of the incoming related particulate fluxes; this proportion will be similar for the riverine particulate silica.

iii. Regional seas intercept $33 \%$ of the related dissolved silica of which about $75 \%$ might not be exchanged with the open ocean.

Some examples of the river silica fluxes to regional seas as calculated by COSCATs aggregations are featured on Table 6. Their ranges in terms of average concentration (1.9 to $17.1 \mathrm{mg} \mathrm{l}^{-1}$ ) and yields $\left(0.4\right.$ to $\left.9.9 \mathrm{t} \mathrm{km}^{-2} \mathrm{y}^{-1}\right)$ are over one order of magnitude and illustrate the multiple control factors already presented.

For each individual ocean drainage basin the actual silica retention in regional seas should now be estimated; it may be quite different from these global figures (Meybeck et al., 2007): the Southern Atlantic Ocean has no mega filter except for the Patagonia platform, therefore retention is very limited. 
The North Atlantic Ocean is very different from the South Atlantic, as it is connected to many regional seas, often interconnected in nested basins as the Mediterranean plus Black Sea, the Gulf of Mexico plus Caribbean - also termed North American Mediterranean -, the Baltic Sea, Hudson Bay and St. Lawrence Gulf (see Table 6 for individual budgets). Their potential silica retention is large ( $40 \%$ for $\mathrm{PSi}, 20 \%$ for $\mathrm{DSi}$, applying the filter types proposed by Meybeck et al., 2007).

The Pacific Ocean is also very much affected by regional seas: (i) its drainage area is already very limited $\left(19.8 \mathrm{M} \mathrm{km}^{2}\right.$ drainage basin area/181.3 $\mathrm{M} \mathrm{km}^{2}$ Pacific Ocean area $=0.11$ ), compared to the world average $\left(114.7 \mathrm{M} \mathrm{km}^{2}\right.$ total exorheic basin area $/ 362 \mathrm{M} \mathrm{km}^{2}$ total ocean area $=0.32$ ) or to the Arctic Ocean $\left(16.7 \mathrm{M} \mathrm{km}^{2}\right.$ drainage basin area/12.3 $\mathrm{M} \mathrm{km}^{2}$ Arctic Ocean area $=1.4$ ); (ii) a larger proportion of its western drainage area (83\%) is actually linked to the West Pacific Mediterranean Regional Seas from Okhotsk to Banda and Sulu Sea (Meybeck et al., 2007); (iii) the Bering Sea, the British Columbia and S. Alaska coast archipelago type of mega filter may also retain an important share of the riverine dissolved silica from the Yukon River to the Fraser River. The net inputs to the open Pacific are probably only half of the riverine inputs arriving at the mouths of the rivers. This is taking into account the position of the regional seas basins only. If the estuarine and shelf filter is considered, this retention might even be higher.

In the Arctic Ocean the mega filters consist mostly of the Siberian platform - a limited mega filter, also termed Siberian Seas, much more connected to the open ocean than the enclosed and semi-enclosed West Pacific regional seas. The consideration of mega-filters is therefore increasing the discrepancy between the Arctic Ocean, relatively well fed by river silica per unit volume of open sea - i.e. without the regional seas and other mega filters -, and the open Pacific Ocean, very much deprived of river silica.

The Indian Ocean has a limited connection to regional seas (e.g. Andaman Sea, Persian Gulf, Red Sea), which are often characterized by minimal river inputs, as for the Red Sea. To our knowledge, the retention of silica inputs from the Ganges-Brahmaputra-Meghna rivers in the Bay of Bengal remains to be established. If it is recognized, the open waters of the Indian Ocean might receive less silica than those of the South Atlantic (Liu et al., 2010).

Open oceans are generally deprived of DSi at their surface due to bioactivity when compared to deeper waters (Levitus et al., 1993). Only in some regions, where COSCATs characterised by high proportions of volcanic rocks drain to the open ocean (e.g., Indonesia, Hawaii, Kamchatka), some increases in surface water DSi concentrations can be observed (if Antarctica and northern Arctic waters are disregarded). Upwelling onto continental margins and subsequent storage due to sedimentation can be a sink for oceanic silica (Tréguer et al., 1995; Laruelle et al., 2009), but these "reverse" fluxes of silica in the land-ocean continuum can currently only be estimated by ocean models and since they do not concern continental silica fluxes to the oceans, they are not discussed further here.

Besides riverine inputs, atmospheric deposition of DSi and PSi is a further important source of "new Si" to the surface oceanic system. Atmospheric PSi dust deposition estimates range globally from $278-489 \mathrm{Mt} \mathrm{yr}^{-1}$ of dust, and 79 to $128 \mathrm{Mt} \mathrm{yr}^{-1} \mathrm{PSi}$ from dust is deposited onto the oceans (Tegen and Kohfeld, 2006), with highest amounts reported for the North Atlantic and the western North Pacific. However, the contribution of atmospheric deposition to the oceanic DSi budget is difficult to estimate and can be attributed to large spatial and temporal differences in DSi in atmospheric deposition as well as uncertainties in quantification of DSi removal from PSi dissolution (cf. Zhang et al., 2005; Baker et al., 2006; Hartmann et al., 2008). For example, it was found that the atmospheric dissolved silica deposition rate (DSi-R), including relatively fast soluble DSi from solid matter in the bulk deposition sampler, on a Japanese watershed, close to the sea, was higher for periods with increased abundance of dust storm events. However, the ratio of DSi-R to solid matter deposition rate (SM-R) decreased with increasing SM-R. The overall observation range (monthly samples over 12 years) suggests a DSi-R/SM-R ratio of about $8 \mathrm{wt} \%$. This high observed ratio is to some part attributed to influences of anthropogenic fly ash with notable amounts of amorphous silica for the East Asian region (cf. Misran et al., 2007; Hartmann et al., 2008), but this amount is globally not equally distributed in aerosols. In general, reported Si-solubility from deposited particulate matter into surface waters ranges from $0.02-1.1 \%$ for aerosols from Saharan dust events deposited over the Atlantic (Baker et al., 2006) to theoretical estimates of 5-10\% (Harrison, 2000; Tréguer et al., 1995). However, these solubility rates are based on the assumption of different dust mineral compositions. For example, Saharan dust contains large amounts of quartz whereas Harrison (2000) uses kinetic considerations to derive potential solubility estimates and assumes that aerosol particles contain large quantities of feldspar. For global ocean models calculating at time scales ranging from years to decades, DSi input from dust is often neglected as it is assumed that deposited aeolian silica would be deposited as sand particles whose sinking speed would not allow any dissolution resulting in a significant input of silicic acid (Johnson et al., 2006). In consequence, a fair estimate of DSi input via the atmosphere into the oceanic system can not be provided, except for the value provided by Tréguer et al. (1995) for DSi inputs via rain water $\left(0.5 \mathrm{Tmol} \mathrm{y}^{-1}\right.$, i.e. $30 \mathrm{Mt} \mathrm{SiO}_{2} \mathrm{y}^{-1}$ (DSi)), which will be used here for our attempt of a global land-to-ocean budget (see below). However, estimated global DSi and PSi deposition on the ocean is much lower than the estimates for riverine DSi. If $30 \mathrm{Mt} \mathrm{SiO}_{2} \mathrm{y}^{-1}$ are deposited over oceans, and we assume a similar deposition over land, $11 \mathrm{MtSiO}_{2} \mathrm{y}^{-1}\left(9.5 \mathrm{MtSiO}_{2} \mathrm{y}^{-1}\right.$ over the exorheic area) might be deposited via rain over continents $\left(362 \mathrm{M} \mathrm{km}^{2}\right.$ of 
ocean area, $133 \mathrm{M} \mathrm{km}^{2}$ of continental area with $115 \mathrm{M} \mathrm{km}^{2}$ being exorheic, according to the numbers in Meybeck et al., 2006, 2007 and Vörösmarty et al., 2000a, b).

The amount of DSi retained in lakes and floodplains can be estimated as a rough first-order calculation as follows: from the work by Lehner and Döll (2004), lake surface can be calculated, plus a certain proportion of the share of a region covered by floodplains; swamps and wetlands. From the share in a given area that is covered by floodplains, swamps and wetlands, we assume $15 \%$ of this share to be permanently flooded - similar to the value proposed by Laruelle et al. (2008) using a global silica box model. This calculation $(100 \%$ of classes 1,3 , and $15 \%$ of classes $4,5,9-$ 12 in Lehner and Döll, 2004) results in a total surface area of $3.4 \mathrm{M} \mathrm{km}^{2}$ of exorheic area occupied by lakes and permanently inundated floodplains, swamps and wetlands. If an average dissolved silica retention of $20 \pm 10 \mathrm{~g} \mathrm{~m}^{-2} \mathrm{y}^{-1}$ is considered (see above, Campy and Meybeck, 1995), this results in $69 \pm 35 \mathrm{MtSiO}_{2} \mathrm{y}^{-1}$ retained in continental areas connected to the oceans. This number corresponds to 1.2 Tmol Si and is somewhat lower than the $2.8 \mathrm{Tmol}$ calculated by Laruelle et al. (2009) as preserved in sediments, but their number includes the volume of rivers, in addition to lakes and floodplains. Yet the average DSi retention in lakes should be confirmed with a larger data set.

Human impacts on the silica fluxes have not been targeted here. They can affect both sources and sinks. As diatomites and/or artificially produced zeoliths are often used in washing powders and other household products (2-3 million metric tons of $\mathrm{SiO}_{2}$, Breese, 1994; van Dokkum et al., 2004), an increase of silica due to urban impacts is possible. Such inputs have been estimated to $780 \mathrm{~g} \mathrm{SiO}_{2}$ (for DSi) per capita per year ( $1 \mathrm{~g}$ of $\mathrm{Si}$ per capita per day) by Sferratore et al. (2006) on Paris megacity (10 million people). The extrapolation to 1 or 2 billions of similar users would correspond to a load of 0.78 to $1.56 \mathrm{M} \mathrm{tDSiO}_{2}$ per year, compared to a river flux of $371 \mathrm{M} \mathrm{tDSiO}_{2} \mathrm{y}^{-1}$ to coastal zones. Based mainly on data from Europe, van Dokkum et al. (2004) estimate the total additional flux due to anthropogenic emissions to be $<=2 \%$ of riverine DSi fluxes. These fluxes might thus be of local importance (e.g., Seine), and are very minor at global scale, but such extrapolation remains poorly constrained.

Additional sinks correspond to the 100000 and more reservoirs already registered (Vörösmarty et al., 2003). They correspond to at least $0.5 \mathrm{M} \mathrm{km}^{2}$ area of registered impoundments, and have been globally estimated to a total area of $1.5 \mathrm{M} \mathrm{km}^{2}$, if smaller and unregistered reservoirs are taken into account (St. Louis et al., 2000). Considering again, as for lakes, an average dissolved silica retention of $20 \pm$ $10 \mathrm{~g} \mathrm{~m}^{-2} \mathrm{y}^{-1}$ (Campy and Meybeck, 1995), the total DSi retention would be of the order of $30 \pm 15 \mathrm{MtSiO}_{2}$ retained each year in reservoirs. This number can be adjusted to $26.4 \pm 13.2 \mathrm{Mt} \mathrm{SiO}_{2}$ (i.e., less than $10 \%$ of the total annual DSi flux to coastal areas) if the distribution of $88 \%$ reservoir area to exorheic regions is taken into account (calculated using the database - containing major reservoirs only - by Lehner and Döll, 2004). This number is lower than the 18$19 \%$ retention calculated by Beusen et al. (2009) based on sediment or inorganic phosphorus retention rates. It must be noted that the retention rate of silica per unit lake or reservoir area considered is about seven times higher than the average weathering rate of silica-bearing minerals. This retention has already been suggested as responsible for the decrease of silica in some large river basins as the Mississippi, where the N:Si ratio has widely fluctuated over the last 100 years (Rabalais and Turner, 2001). Other cases of silica-depleted coastal waters have also been reported for Swedish rivers and in the Danube River delta (Humborg et al., 1997, 2000, 2006), invoking also alternative human impact mechanisms such as reduced connectivity with usually DSi-rich aquifers due to hydraulic alterations, resulting in less exchanges with the riparian zone or lower natural water levels controlling silicon weathering rates (Teodoru et al., 2006). While there is now a considerable amount of literature (e.g., Vörösmarty et al., 2003; Syvitski et al., 2005) on the anthropogenic overprint of suspended matter fluxes, it is outside the scope of this paper to add to this discussion. For suspended particulate matter (SPM), and thus detrital PSi, global retention in reservoirs (yet partly balanced by increased deforestation leading to enhanced denudation) is now estimated between $20 \%$ (Syvitski et al., 2005) and 30\% (Vörösmarty et al., 2003). Additional retention of DSi can occur in main stems of rivers and is closely related to anthropogenic influence on nitrogen (N) and phosphorus (P) levels. Significant amounts of BSi resulting from plankton blooms can be sedimented in flood plains (Admiraal et al., 1990). As early data from European rivers suggests (see above), DSi retention due to $\mathrm{N}$ and $\mathrm{P}$ fertilization may possibly occur since the middle of the 19th century (Roth, 1879). N and P fertilization might thus cause decreases in DSi levels in urbanized or agricultural catchments. When recent decreases of $\mathrm{N}$ and $\mathrm{P}$ in managed rivers are observed, it has been noted that DSi concentrations might eventually come back to nearly pristine levels, as data from the Rhine River suggest (Hartmann et al., 2010b). It must be noted that long-term records of DSi in rivers are much less common than those for $\mathrm{N}$ and $\mathrm{P}$.

Retention in lakes, floodplains, and human-built reservoirs is very much dependant on water residence times in these bodies, and our simple calculation for the global scale should be verified by further studies. The assumed retention rate of $20 \pm 10 \mathrm{~g} \mathrm{~m}^{-2} \mathrm{y}^{-1}$ by Campy and Meybeck (1995) is a crude estimate that has been derived for few lakes, and is probably lower for reservoirs and highly anthropised floodplains, due to lower residence times.

If our first-order back-of-the-envelope estimate, proposed here as a working hypothesis, is validated in forthcoming studies, the total amount of dissolved silica in headwaters, derived from weathering on the exorheic parts of the continents should be increased by as much as $59 \mathrm{MtSiO}_{2}$ per year (additional retention of $69 \pm 35 \mathrm{Mt} \mathrm{SiO}_{2}$ as $\mathrm{BSi}$ in lakes, 


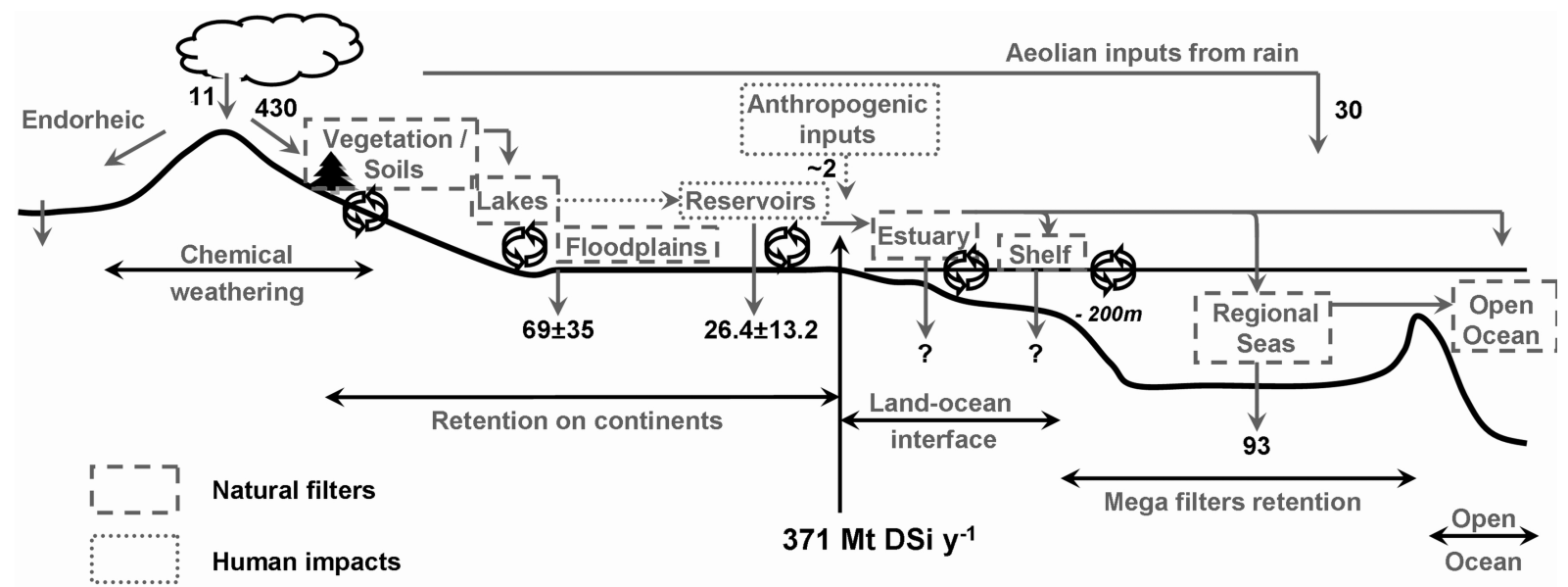

Fig. 6. Conceptual pathways of dissolved silica from land to oceans with cascading filters on land and nested filters at the land-ocean interface. Dotted: anthropogenic components. All numbers are in Mt DSi per year.

floodplains, swamps and wetlands for the natural situation, minus $9.5 \mathrm{Mt} \mathrm{SiO}_{2}$ from atmospheric deposition), assuming that riverine DSi derived from re-dissolution of BSi ultimately also stems from weathering sources. While there is still considerable uncertainty on control factors, the budget seems well constrained.

A schematic view on the silica transfers from land to ocean with the cascading filters, both natural and anthropogenic, and new anthropogenic inputs that characterize the Anthropocene (Crutzen and Stoermer, 2000) situation of river systems described by Meybeck and Vörösmarty (2005), is presented in Fig. 6. It is combined with the nested filters of river inputs to oceans: estuaries, shelf, regional seas and other mega filters.

\section{Conclusions and perspectives}

The spatialized distribution of riverine dissolved silica fluxes has been realised for $\sim 140$ coastal catchments (COSCATs). The documented area and river runoff correspond to 56 and $58 \%$ of the globe, respectively, and the documented river DSi fluxes to $51 \%$. The undocumented part is extrapolated on the basis of modelled runoff, and of regional similarities of dissolved silica based on lithology, climate and lake occurrence. Some of the COSCATs are still lacking analyses (e.g. Madagascar island and parts of Australasia), but the spatial coverage of the 250+ rivers used in this budget is not biased for any of the control factors. The resulting overall dissolved silica average $\left(9.5 \mathrm{mg} \mathrm{l}^{-1}\right)$ is not much different from previous attempts of the last decade, but the spatialization of average concentrations and yields for each piece of the COSCAT puzzle is new.

At such resolution (ca. $1 \mathrm{M} \mathrm{km}^{2}$ ), the average DSi concentrations for COSCATs range over one order of magnitude and a factor of 50 for DSi yields. The highly skewed distribution of yields results in a marked imbalance of riverine fluxes: at the global scale, $55 \%$ of dissolved silica fluxes originate from only $17.4 \%$ of the land area facing the oceans, while $28.9 \%$ of this area contribute to only $2.3 \%$ of fluxes. Similar skewed distributions have been found for many other river-borne materials. Higher fluxes originate from different COSCATs, encountered on many continents: they correspond to high to very high runoff rates, combined with medium and high relief, volcanic and/or highly active tectonic regions, the major control factors of silica sources. The occurrence of multiple lakes or of single large lakes (e.g. Saint Lawrence basin, COSCAT \#825, with the Great Lakes, or Gulf of Finland basin, COSCAT \#0406 with the Neva River showing one of the world's lowest silica yields due to the presence of Lake Ladoga close to its outlet, combined to a cold climate) is probably a major control factor of silica retention on continents.

Partitioning silica outputs between individual continents has little interest since they generally combine both high and low yields as demonstrated when considering individual COSCATs.

The riverine silica inputs to individual oceans, required by ocean biogeochemists, show great disparities when considering relative fluxes received per unit ocean area or volume: there is nearly one order of magnitude difference between the fluxes to the Arctic Ocean (silica over-fed) and the Pacific (silica-starving). This type of computation should now also take into account the nested filtering effects of estuaries, shelves and regional seas: the discrepancy between the silica fluxes received by the Pacific after the potential retention of DSi by regional seas may be even greater, compared to those received by the Arctic.

When comparing the riverine yields of dissolved silica $\left(Y_{\mathrm{DSi}}\right)$ and of particulate silica $\left(Y_{\mathrm{PSi}}\right)$ - at the COSCAT resolution, assuming a constant silica content around $55 \% \mathrm{SiO}_{2}$ 
in river suspended matter - a weak positive correlation is found, with the Pohai Gulf (COSCAT \#1325) including the HuangHe basin set aside. The $Y_{\mathrm{DSi}} / Y_{\mathrm{PSi}}$ ratio in COSCATs ranges from more than unity to $10^{-4}$ (HuangHe). A majority of COSCATs has a ratio between 0.005 and 0.5 , compared to the global flux ratio $\left(\overline{Y_{\mathrm{DSi}}} / \overline{Y_{\mathrm{PSi}}}=0.042\right)$. $9 \%$ of the COSCAT area $\left(10.3 \mathrm{M} \mathrm{km}^{2}\right)$ are constituted by regions where the particulate transfers are very high $\left(\overline{Y_{\mathrm{DSi}}} / \overline{Y_{\mathrm{PSi}}}<\right.$ 0.01), as for the Pohai Gulf.

Future development of ocean budgets should therefore aim at regional budgets in which river inputs are spatially distributed (Liu et al., 2010). These biogeochemical models combine all river nutrients $(\mathrm{N}, \mathrm{P}, \mathrm{Si})$ and carbon species (Sferratore et al., 2005), including the retention impact of reservoirs that is not yet fully quantified at the global scale.

The improvement of the silica budget coverage, e.g. from the actual $50-60 \%$ coverage to $75 \%$, will not be easily achieved. There are only few major rivers, such as the Salween and Irrawaddy, that remain undocumented in the database used here and the inclusion of hundreds of small and medium basins $\left(0.01\right.$ to $\left.0.1 \mathrm{M} \mathrm{km}^{2}\right)$ would be needed: the first 10 rivers, ranked by basin area, correspond to about $26 \%$ of the global exorheic area, the first 100 to $62 \%$ and the first 1000 to 74\% only (Milliman and Syvitski, 1992; Meybeck and Ragu, 1995).

Further research should first estimate each of the components of the global silica cycle (Fig. 6), then establish these fluxes for individual regions and/or ocean basins and we have seen that major disparities exist in silica concentrations or yields.

A most promising approach is represented by biogeochemical models that are spatially distributed at very high resolution linking sources (weathering) and sinks (uptake, sedimentation of biogenic silica), as already developed for the Seine River (Sferratore et al., 2005) and the Red River (Hong) in Vietnam, in connection with $\mathrm{N}$ and $\mathrm{P}$ models (Quynh et al., 2005). This type of model is often datalimited and should now be validated for different types of river basins. Also the analysis of riverine particulate biogenic silica, either detrital or phytoliths, or autochthonous, should be further developed, particularly in highly eroded river basins, and compared to the particulate organic carbon. These models will be able to simulate the silica retention in reservoirs and explore Global Change scenarios on the riverine components of the silica cycle.

\section{Supplementary material related to this article is available online at: http://www.biogeosciences.net/8/597/2011/ bg-8-597-2011-supplement.pdf.}

Acknowledgements. This paper is dedicated to Fred Mackenzie and Robert Berner who paved the way of global riverine chemistry. The original idea for this work came from the Si-WEBS project, an EU Research Training Network. This project was made possible by financial support from Utrecht University (High Potential project G-NUX) and the EU (Si-WEBS, contract number HPRN-CT-2002000218). The work of Jens Hartmann is funded by the German Science Foundation (DFG-project HA 4472/6-1 and the Cluster of Excellence "CliSAP” (EXC177), Universität Hamburg). Charles Vörösmarty (Water Systems Analysis Group, University of New Hampshire, USA) is acknowledged for the communication of various data sets. We thank two anonymous reviewers who helped to clarify and improve the manuscript.

Edited by: J. Middelburg

\section{References}

Admiraal, W., Breugem, P., Jacobs, D. M. L. H. A., and de Ruyter van Steveninck, E. D.: Fixation of dissolved silicate and sedimentation of biogenic silicate in the lower river Rhine during diatom blooms, Biogeochemistry, 9(2), 175-185, 1990.

Alekin, O. A. and Brazhnikova, L. V.: Contribution à la connaissance de l'écoulement des substances dissoutes de la surface terrestre du globe, Gidrochim. Mat., 32, 12-34, 1960.

Alekin, O. A. and Brazhnikova, L. V.: Sur la corrélation entre le transport ionique et celui des substances en suspension, Dokl. Acad. Nauk. SSSR, 146(1), 203-206, 1962.

Alekin, O. A. and Brazhnikova, L. V.: Dissolved matter discharge and mechanical and chemical erosion, Ass. Int. Hydrol. Sci. Publ., 78, 35-41, 1968.

Amiotte-Suchet, P., Probst, J.-L., and Ludwig, W.: Worldwide distribution of continental rock lithology: Implications for the atmospheric/soil $\mathrm{CO}_{2}$ uptake by continental weathering and alkalinity river transport to the oceans, Global Biogeochem. Cy., 17(2), 1038, doi:10.1029/2002GB001891, 2003.

Aston, S. R.: Natural Water and Atmospheric Chemistry of Silicon, in: Silicon Geochemistry and Biogeochemistry, edited by: Aston, S. R., Academic Press, London, 77-100, 1983.

Aumont, O., Orr, J. C., Monfray, P., Ludwig, W., Amiotte-Suchet, P., and Probst, J.-L.: Riverine-driven interhemispheric transport of carbon, Global Biogeochem. Cy., 15, 393-405, 2001.

Baker, A. R., French, M., and Linge, K. L.: Trends in aerosol nutrient solubility along a west-east transect of the Saharan dust plume, Geophys. Res. Lett., 33, L07805, doi:10.1029/2005GL024764, 2006.

Balls, P. W.: Nutrient Inputs to Estuaries from Nine Scottish East Coast Rivers; Influence of Estuarine Processes on Inputs to the North Sea, Estuar. Coast. Shelf S., 39, 329-352, 1994.

Bartoli, F.: The biogeochemical cycle of silicon in two temperate forest ecosystems, Ecol. Bull., 35, 469-476, 1983.

Bernard, C. Y., Dürr, H. H., Heinze, C., Segschneider, J., and Maier-Reimer, E.: Contribution of riverine nutrients to the silicon biogeochemistry of the global ocean - a model study, Biogeosciences, 8, 551-564, doi:10.5194/bg-8-551-2011, 2011.

Berner, E. K. and Berner, R. A.: Global Environment: Water, Air, and Geochemical Cycles, Prentice Hall, Upper Saddle River, New Jersey, 376 pp., 1996.

Beucher, C.: Production et dissolution de la silice biogène dans les écosystèmes marins; mesure par spectrométrie de masse, $\mathrm{Ph} . \mathrm{D}$ thesis, Université de Bretagne Occidentale, Brest, 181 pp., 2003.

Beusen, A. H. W., Dekkers, A. L. M., Bouwman, A. F., Ludwig, W., and Harrison, J.: Estimation of global river transport of 
sediments and associated particulate $\mathrm{C}, \mathrm{N}$, and P, Global Biogeochem. Cy., 19, GB4S05, doi:10.1029/2005GB002453, 2005.

Beusen, A. H. W., Bouwman, A. F., Dürr, H. H., Dekkers, A. L. M., and Hartmann, J.: Global patterns of dissolved silica export to the coastal zone: Results from a spatially explicit global model, Global Biogeochem. Cy., 23, GB0A02, doi:10.1029/2008GB003281, 2009.

Billen, G. and Garnier, J.: The Phison River Plume: coastal eutrophication in response to changes in land use and water management in the watershed, Aquat. Microb. Ecol., 13, 3-17, 1997.

Bluth, G. J. S. and Kump, L. R.: Lithologic and climatologic controls of river chemistry, Geochim. Cosmochim. Ac., 58, 23412359, 1994.

Boeglin, J. L. and Probst, J. L.: Physical and chemical weathering rates and $\mathrm{CO}_{2}$ consumption in a tropical lateritic environment: the upper Niger basin, Chem. Geol., 148(3-4), 137-156, 1998.

Breese, R. O. Y.: Diatomite, in: Industrial Mineral and Rocks, edited by: Carr, D. D., 397-412, 1994.

Brunskill, G. J.: Environmental features of the Mackenzie system, in: The Ecology of River Systems, edited by: Davies, B. R. and Walker, K. F., W. Junk Publishers, Dordrecht, Chapter 16A, 435471, 1986.

Campy, M. and Meybeck, M.: Les sédiments lacustres, in: Limnologie Générale, edited by: Pourriot, R. and Meybeck, M., Masson, Paris, 184-226, 1995.

Canfield, D.: The geochemistry of river particulates from the continental USA: major elements, Geochim. Cosmochim. Ac., 61, 3349-3365, 1997.

Chou, L. and Wollast, R.: Estuarine Silicon Dynamics, in: The Silicon Cycle - Human Perturbations and Impacts on Aquatic Systems, edited by: Ittekot, V., Unger, D., Humborg, C., and TacAn, N., SCOPE 66, Island Press, Washington, 93-120, 2006.

Clarke, F. W.: Data of geochemistry, Vth edn., No. 770, U.S.G.S. Survey Bull., 841 pp, 1924.

Conley, D. J.: Riverine contribution of biogenic silica to the oceanic silica budget, Limnol. Oceanogr., 42(4), 774-777, 1997.

Conley, D. J.: Terrestrial ecosystems and the global biogeochemical silica cycle, Global Biogeochem. Cy., 16(4), 1121, doi:10.1029/2002GB001894, 2002.

Conley, D. J., Stalnacke, P., Pitkanen, H., and Wilander, A.: The transport and retention of dissolved silicate by rivers in Sweden and Finland, Limnol. Oceanogr., 45(8), 1850-1853, 2000.

Conley, D. J., Likens, G. E., Buso, D. C., Saccone, L., Bailey, S. W., and Johnson, C. E.: Deforestation causes increased dissolved silicate losses in the Hubbard Brook Experimental Forest, Glob. Change Biol., 14(11), 2548-2554, 2008.

Cornelis, J.-T., Delvaux, B., Georg, R. B., Lucas, Y., Ranger, J., and Opfergelt, S.: Tracing the origin of dissolved silicon transferred from various soil-plant systems towards rivers: a review, Biogeosciences, 8, 89-112, doi:10.5194/bg-8-89-2011, 2011.

Crutzen, P. J. and Stoermer, E. F.: The "Anthropocene", IGBP Newsletter, 41, 17-18, 2000.

Dagg, M., Benner, R., Lohrenz, S., and Lawrence, D.: Transformation of dissolved and particulate materials on continental shelves influenced by large rivers: plume processes, Cont. Shelf Res., 24, 833-858, 2004.

DeMaster, D. J.: The Supply and accumulation of silica in the marine environment, Geochim. Cosmochim. Ac., 45, 1715-1732, 1981.
DeMaster, D. J.: The accumulation and cycling of biogenic silica in the Southern Ocean: revisiting the marine silica budget, DeepSea Res. Pt. II, 49, 3155-3167, 2002.

DeMaster, D. J., Knapp, G. B., and Nittrouer, C. A.: Biological uptake and accumulation of silica on the Amazon continental shelf, Geochim. Cosmochim. Ac., 47, 1713-1723, 1983.

Depetris, P. J. and Paolini, J. E.: Biogeochemical Aspects of South American Rivers: The Parana and the Orinoco, in: Biogeochemistry of Major World Rivers, edited by: Degens, E. T., Kempe, S., and Richey, J. E., 5, 105-125, 1991.

Depetris, P. J., Gaiero, D. M., Probst, J.-L., Hartmann, J., and Kempe, S.: Biogeochemical output and typology of rivers draining Patagonia's Atlantic seaboard, J. Coastal Res., 21(4), 835844, 2005.

de Villiers, P. R.: The chemical composition of the water of the Orange river at Vioolsdrif, Cape Province, Annals of the Geological Survey, Rep. South Africa, 5(1), 198-206, 1962.

Drever, J. I.: The effect of land plants on weathering rates of silicate minerals, Geochim. Cosmochim. Ac., 58, 2325-2332, 1994.

Drever, J. I.: The Geochemistry of Natural Waters: Surface and Groundwater Environments, Prentice-Hall, Upper Saddle River, New Jersey, 436 pp., 1997.

Dumont, E., Harrison, J. A., Kroeze, C., Bakker, E. J., and Seitzinger, S. P.: Global distribution and sources of dissolved inorganic nitrogen export to the coastal zone: Results from a spatially explicit, global model, Global Biogeochem. Cy., 19, GB4S02, doi:10.1029/2005GB002488, 2005.

Dürr, H. H., Meybeck, M., and Dürr, S. H.: Lithologic composition of the Earth's continental surfaces derived from a new digital map emphasizing riverine material transfer, Global Biogeochem. Cy., 19, GB4S10, doi:10.1029/2005GB002515, 2005.

Fairbridge, R. W. (Ed.): The Encyclopedia of Oceanography, Van Nostrand Rheinhold, New York, 1021 pp., 1966.

Fekete, B. M., Vörösmarty, C. J., and Grabs, W.: High-resolution fields of global runoff combining observed river discharge and simulated water balances, Global Biogeochem. Cy., 16(3), 1042, doi:10.1029/1999GB001254, 2002.

Gaiero, D. M., Depetris, P. J., Probst, J.-L., Bidart, S. M., and Leleyter, L.: The signature of river- and wind-borne materials exported from Patagonia to the southern latitudes: a view from REEs and implications for paleoclimatic interpretations, Earth Planet. Sc. Lett., 219, 357-376, 2004.

Gaillardet, J., Dupré, B., Louvat, P., and Allègre, C. J.: Global Silicate weathering and $\mathrm{CO}_{2}$ consumption rates deduced from the chemistry of large rivers, Chem. Geol., 159, 3-30, 1999.

Galy, A. and France-Lanord, C.: Weathering processes in the Ganges-Brahmaputra basin and the riverine alkalinity budget, Chem. Geol., 159(1-4), 31-60, 1999.

Garnier, J., Sferratore, A., Meybeck, M., Billen, G., and Dürr, H.: Modelling silica transfer processes in river catchments, in: Role of Silica in Land-Sea Interactions, edited by: Ittekkot, V., Unger, D., Humborg, C., and Tac An, N., SCOPE book series, Island Press, 139-162. 2006.

Garrels, R. M. and Mackenzie, F. T.: Origin of chemical compositions of some springs and lakes., Adv. Chem. Ser., 222-242, 1967.

Garrels, R. M. and Mackenzie, F. T.: Evolution of Sedimentary Rocks, Norton \& Co. Inc., New York, 397 pp., 1971.

Garrels, R. M., Mackenzie, F. T., and Hunt, C.: Chemical Cycles 
and the Global Environment, William Kaufman Inc., Los Altos, CA, 206 pp., 1973.

Gerasimov, G. N., et al. (Eds.): Physico-Geographical World Atlas, Scientific Academy of URSS and Cartographic and Geodesic Central Committee, Moscow, 298 pp., 1964.

Glazovsky, N. F.: Change in the Anthropogenic geochemical impact on the Biosphere, GeoJournal, 20(2), 115-119, 1990.

Godderis, Y., Roelandt, C., Schott, J., Pierret, M. C., and Francois, L. M.: Towards an Integrated Model of Weathering, Climate, and Biospheric Processes, Thermodynamics and Kinetics of WaterRock Interaction, 70, 411-434, 2009.

Gölz, E.: Mineralogisch-petrographische Untersuchungen an Schwebstoffen und feinkörnigen Sedimenten des Rheins, BFG - Bundesanstalt für Gewässerkunde, Report G1/435.06/3600, 42 pp., 1982.

Gordeev, V. V. and Lisitzin, A. P.: Average chemical composition of suspended matter in world river and river inputs to the oceans, Dokl. Akad. Nauk. SSSR, 238, 225-228, 1978.

Green, P., Vörösmarty, C. J., Meybeck, M., Galloway, J., Peterson, B., and Boyer, E.: Pre-Industrial and Contemporary Fluxes of Nitrogen through Rivers: A Global Assessment Based on Typology, Biogeochemistry, 68, 71-105, 2004.

Harrison, K. G.: Role of increased marine silica input on paleo$\mathrm{pCO}_{2}$ levels, Paleoceanography, 15, 292-298, 2000.

Harrison, J. A., Seitzinger, S. P., Bouwman, A. F., Caraco, N. F., Beusen, A. H. W., and Vörösmarty, C. J.: Dissolved inorganic phosphorus export to the coastal zone: Results from a spatially explicit, global model, Global Biogeochem. Cy., 19, GB4S03, doi:10.1029/2004GB002357, 2005.

Hartmann, J.: Long-term seismotectonic influence on the hydrochemical composition of a spring located at Koryaksky-Volcano, Kamchatka: deduced from aggregated earthquake information, Int. J. Earth Sci., 95(4), 649-664, 2006.

Hartmann, J. and Moosdorf, N.: Chemical weathering rates of silicate-dominated lithological classes and associated liberation rates of phosphorus on the Japanese Archipelago - Implications for global scale analysis, Chem. Geol., doi:10.1016/j.chemgeo.2010.12.004, in press, 2010.

Hartmann, J., Kunimatsu, T., and Levy, J. K.: The impact of Eurasian dust storms and anthropogenic emissions on atmospheric nutrient deposition rates in forested Japanese catchments and adjacent regional seas, Global Planet. Change, 61, 117-134, doi:10.1016/j.gloplacha.2007.08.001, 2008.

Hartmann, J., Jansen, N., Kempe, S., Dürr, H. H., and Köhler, P.: Global $\mathrm{CO}_{2}$-consumption by chemical weathering: What is the contribution of highly active weathering regions?, Global Planet. Change, 69, 185-194, doi:10.1016/j.gloplacha.2009.07.007, 2009.

Hartmann, J., Jansen, N., Dürr, H. H., Harashima, A., Okubo, K., and Kempe, S.: Predicting riverine dissolved silica fluxes into coastal zones from a hyperactive region and analysis of their first order controls, Int. J. Earth Sci., 99, 207-230, doi:10.1007/s00531-008-0381-5, 2010a.

Hartmann, J., Levy, J. K., and Kempe, S.: Increasing dissolved silica trends in the Rhine River: an effect of recovery from high P loads?, Limnology, doi:10.1007/s10201-010-0322-4, in press, 2010b.

Hartmann, J., Dürr, H. H., Moosdorf, N., Meybeck, M., and Kempe, S.: The geochemical composition of the terrestrial surface (with- out soils) and comparison with the upper continental crust, Int. J. Earth Sci., doi:10.1007/s00531-010-0635-x, in press, 2011.

Holland, H. D.: Sea level, sediments and the composition of seawater. Am. J. Sci., 305(3), 220-239, 2005.

Humborg, C., Ittekkot, V., Cociasu, A., and von Bodungen, B.: Effect of Danube River dam on Black Sea biogeochemistry and ecosystem structure, Nature, 386, 385-388, 1997.

Humborg, C., Conley, D. J., Rahm, L., Wulff, F., Cociasu, A., and Ittekot, V.: Silica retention in river basins: far reaching effects on biogeochemistry and aquatic food webs, Ambio, 29, 45-50, 2000.

Humborg, C., Pastuszak, M., Aigars, J., Siegmund, H., Mörth, C.M., and Ittekkot, V.: Decreased silica land-sea fluxes through damming in the Baltic Sea catchment - significance of particle trapping and hydrological alterations, Biogeochemistry, 77, 265 281, 2006.

Humborg, C., Smedberg, E., Medina, M. R., and Mörth, C.,M.: Changes in dissolved silicate loads to the Baltic Sea - The effects of lakes and reservoirs, J. Marine Syst., 73(3-4), 223-235, 2008.

Isaji, C.: Silica fractionation: a method and differences between two Japanese reservoirs, Hydrobiologia, 504, 31-38, 2003.

Jansen, N., Hartmann, J., Lauerwald, R., Dürr, H. H., Kempe, S., Loos, S., and Middelkoop, H.: Dissolved silica mobilization in the conterminous USA, Chem. Geol., 270, 90-109, doi:10.1016/j.chemgeo.2009.11.008, 2010.

Jennerjahn, T. C., Knoppers, B. A., de Souza, W. F. L., Brunskill, G. J., Silva, I. L., and Adi, S.: Factors controlling dissolved silica in tropical rivers, in: The Silicon Cycle - Human Perturbations and Impacts on Aquatic Systems, edited by: Ittekot, V., Unger, D., Humborg, C., and Tac An, N., SCOPE 66, Island Press, Washington, 29-51, 2006.

Johnson, H. P., Hautala, S. L., Bjorklund, T. A., and Zametske, M. R.: Quantifying the North Pacifica silica plume, Geochem. Geophy. Geosy., 7(5), Q05011, doi:10.1029/2005GC001065, 2006.

Kimmerer, W.: Long-term changes in apparent uptake of silica in the San Francisco estuary, Limnol. Oceanogr., 50, 793-798, 2005.

Kobayashi, J.: Chemical investigation on river waters of southeastern asiatic countries (report I.), The quality of waters of Thailand, Berichte Ohara Inst. für Landwirtschaft Biologie, 11(2), 167233, 1959.

Kobayashi, J.: A chemical study of the average quality and characteristics of river waters of Japan, Berichte Ohara Inst. für Landwirtschaft Biologie, 11(3), 313-357, 1960.

Kobayashi, J.: Silica in fresh water and estuaries, in: Chemical Environment in the Aquatic Habitat, Int. Biosphere Programme Symposium, Amsterdam, 41-55, 1966.

Koroleff, F.: Determination of silicon, in: Methods of seawater analysis. Second, revised and extended edition, edited by: Grasshoff, K., Ehrhardt, M., and Kremling, K., Verlag Chemie, Weinheim, Deerfield Beach, Florida, Basel, 174-187, 1983.

Kossinna, E.: Die Tiefen des Weltmeeres, Vol. 9., Veröffentlichungen Inst. Meereskunde, E. S. Mittler und Sohn, Berlin Univ., 70 pp. (quoted by Viglieri, 1966), 1921.

Laruelle, G. G., Roubeix, V., Sferratore, A., Brodherr, B., Ciuffa, D., Conley, D. J., Dürr, H. H., Garnier, J., Lancelot, C., Le Thi Phuong, Q., Meunier, J.-D., Meybeck, M., Michalopoulos, P., Moriceau, B., Longphuirt, S. N., Loucaides, S., Papush, L., Presti, M., Ragueneau, O., Regnier, P. A. G., Saccone, L., Slomp, 
C. P., Spiteri, C., and Van Cappellen, P.: Anthropogenic perturbations of the silicon cycle at the global scale: the key role of the land-ocean transition, Global Biogeochem. Cy., 23, GB4031, doi:10.1029/2008GB003267, 2009.

Lehner, B. and Döll, P.: Development and validation of a global database of lakes, reservoirs and wetlands, J. Hydrol., 296(1-4), 1-22, 2004.

Le Thi Phuong, Q., Billen, G., Garnier, J., Théry, S., Fézard, C., and Minh, C. V.: Nutrient (N,P) budgets for the Red River basin (Vietnam and China), Global Biogeochem. Cy., 19, GB2022, doi:10.1029/2004GB002405, 2005.

Levitus, S., Conkright, M. E., Reid, J. L., Najjar, R. G., and Mantyla, A.: Distribution of Nitrate, Phosphate and Silicate in the World Oceans, Prog. Oceanogr., 31(3), 245-273, 1993.

Lewis Jr., W. M. and Saunders III, J. F.: Concentrations and transport of dissolved and suspended substances in the Orinoco river, Biogeochemistry, 7, 203-240, 1989.

Liu, K. K., Atkinson, L., Quinones, R., and Talaue-McManus, L. (Eds.): Carbon and nutrient fluxes in continental margins, Springer, IGBP Series, 741 pp., 2010.

Livingstone, D. A.: Chemical composition of rivers and lakes, Data of geochemistry chapter G., U.S. Geol. Survey Prof. Paper, 440 G, G1-G64, 1963.

Ludwig, W. and Probst, J.-L.: River sediment discharge to the oceans: present-day controls and global budgets, Am. J. Sci., 298, 265-295, 1998.

Ludwig, W., Probst, J.-L., and Kempe, S.: Predicting the oceanic input of organic carbon by continental erosion, Global Biogeochem. Cy., 10(1), 23-41, 1996.

Lyons, W. B., Carey, A. E., Hicks, D. M., and Nezat, C. A.: Chemical weathering in high-sediment-yielding watersheds, New Zealand, J. Geophys. Res.-Earth, 110, F01008, doi:10.1029/2003JF000088, 2005.

Mackenzie, F. T. and Garrels, R. M.: Chemical mass balance between rivers and oceans, Am. J. Sci., 264, 507-525, 1966.

Mackenzie, F. T. and Kump, L. R.: Reverse Weathering, Clay Mineral Formation, and Oceanic Element Cycles, Science, 270, 586587, 1995.

Martin, J. M. and Meybeck, M.: Elemental mass-balance of material carried by major world rivers, Mar. Chem., 7, 173-206, 1979.

McKee, B. A.: RiOMar: The Transport, Transformation and Fate of Carbon in River-dominated Ocean Margins, Report of the RiOMar Workshop, 1-3 November 2001, Tulane University, New Orleans, LA, available at: http://www.tulane.edu/ riomar/, 2003.

Meunier, J.-D., Colin, F., and Alarcon, C.: Biogenic silica storage in soils, Geology, 27, 835-838, 1999.

Meybeck, M.: Concentrations des eaux fluviales en éléments majeurs et apports en solution aux océans, Rev. Geol. Dyn. Geogr., 21(3), 215-246, 1979.

Meybeck, M.: Composition chimique des ruisseaux non pollués de France, Sciences Géologiques Bulletin, Strasbourg, 39, 3-77, 1986.

Meybeck, M.: Global chemical weathering of surficial rocks estimated from river dissolved loads, Am. J. Sci., 287, 401-428, 1987.

Meybeck, M.: How to establish and use world budgets of riverine materials, in: Physical and chemical weathering in geochemical cycles, edited by: Lerman, A. and Meybeck, M., Kluwer Academic Publishers, Dordrecht, 247-272, 1988.

Meybeck, M.: C, N, P and S in rivers: from sources to global inputs, in: Interaction of C, N, P and S biogeochemical cycles and global change, edited by: Wollast, R., Mackenzie, F. T., and Chou, L., Springer Verlag, 163-193, 1993.

Meybeck, M.: Origin and variable composition of present day riverborne material, Material Fluxes on the Surface of the Earth, Nat. Academy Press, Washington DC, 61-73, 1994.

Meybeck, M.: Global lake distribution, in: Physics and Chemistry of Lakes, edited by: Lerman, A., Imboden, D., and Gat, J., Springer, 1-35, 1995.

Meybeck, M.: Global occurrence of major elements in rivers, in: Treatise on Geochemistry, edited by: Holland, H. D. and Turekian, K. K., Pergamon, 207-224, 2003.

Meybeck, M. and Dürr, H. H.: Cascading filters of river material from headwaters to regional seas: the European example, in: Watersheds, Bays, and Bounded Seas - The Science and Management of Semi-Enclosed Marine Systems, edited by: Urban Jr., E. R., Sundby, B., Malanotte-Rizzoli, P., and Melillo, J. M., SCOPE Series 70, Washington, Island Press, 115-139, 2009.

Meybeck, M. and Ragu, A.: GEMS/Water Contribution to the Global Register of River Inputs (GLORI), Provisional Final Report, UNEP/WHO/UNESCO, Geneva, 245 pp., 1995.

Meybeck, M. and Vörösmarty, C.: Fluvial filtering of land-to-ocean fluxes: from natural Holocene variations to Anthropocene, C. R. Geosci., 337, 107-123, 2005.

Meybeck, M., Green, P., and Vörösmarty, C.: A New Typology for Mountains and Other Relief Classes, Mt. Res. Dev., 21(1), 3445, 2001 .

Meybeck, M., Dürr, H. H., and Vörösmarty, C. J.: Global coastal segmentation and its river catchment contributors: a new look at land-ocean linkage, Global Biogeochem. Cy., 20, GB1S90, doi:10.1029/2005GB002540, 2006.

Meybeck, M., Dürr, H. H., Roussennac, S., and Ludwig, W.: Regional Seas and their interception of riverine fluxes to oceans, Mar. Chem., 106 (Wollast Memorial Special Issue), 301-325, 2007.

Michalopoulos, P. and Aller, R. C.: Rapid clay mineral formation in Amazon delta sediments: reverse weathering and oceanic elemental fluxes, Science, 270, 614-617, 1995.

Michalopoulos, P. and Aller, R. C.: Early diagenesis of biogenic silica in the Amazon delta: Alteration, authigenic clay formation, and storage, Geochim. Cosmochim. Ac., 68(5), 1061-1085, 2004.

Michalopoulos, P., Aller, R. C., and Reeder, R. J.: Conversion of diatoms to clays during early diagenesis in tropical, continental shelf muds, Geology, 28, 1095-1098, 2000.

Milliman, J. D. and Syvitski, J. P. M.: Geomorphic/Tectonic Control of Sediment Discharge to the Ocean: The Importance of Small Mountainous Rivers, J. Geol., 100, 525-544, 1992.

Millot, R., Gaillardet, J., Dupré, B., and Allègre, C. J.: The global control of silicate weathering rates and the coupling with physical erosion: new insights from rivers of the Canadian Shield, Earth Planet Sc. Lett., 196(1-2), 83-98, 2002.

Misran, H., Singh, R., Begum, S., and Yarmo, M. A.: Processing of mesoporous silica materials (MCM-41) from coal fly ash, J. Mater. Process. Tech., 186, 8-13, 2007.

Moatar, F. and Meybeck, M.: Riverine fluxes of pollutants: Towards 
predictions of uncertainties by flux duration indicators, C. R. Geosci., 339, 367-382, 2007.

Moosdorf, N., Hartmann, J., and Dürr, H. H.: Lithological composition of the North American continent and implications of lithological map resolution for dissolved silica flux modeling, Geochem. Geophy. Geosy., 11, Q11003, doi:10.1029/2010GC003259, 2010.

Mortatti, J. and Probst, J.-L.: Silicate rock weathering and atmospheric/soil $\mathrm{CO}_{2}$ uptake in the Amazon basin estimated from river water geochemistry: seasonal and spatial variations, Chem. Geol., 197(1-4), 177-196, 2003.

Nelson, D. M., Smith Jr., W. O., Muench, R. D., Gordon, L. I., Sullivan, C. W., and Husby, D. M.: Particulate matter and nutrient distribution in the ice edge zone of the Weddell Sea: relationship to hydrography during late summer, Deep-Sea Res., 36, 191209, 1989.

Nixon, S. W.: Chesapeake Bay nutrient budgets - a reassessment, Biogeochemistry, 4, 77-90, 1987.

Oki, T., Agata, Y., Kanae, S., Saruhashi, T., Yang, D., and Musiake, K.: Global Assessment of Current Water Resources using Total Runoff Integrating Pathways, Hydrolog. Sci. J., 46, 983-996, 2001.

Olivry, J. C. and Noah, E.: Qualité des eaux de quelques rivières du Cameroun méridional, ONAREST, Yaoundé, Cameroun, 39 pp., 1978.

Orange, D.: Hydroclimatologie du Fouta Djalon et dynamique actuelle d'un vieux paysage latéritique (Afrique de l'Ouest), Thèse de Docteur de l'Université, Université Louis Pasteur, Sciences Géologiques Mémoires 93, Strasbourg, 198 pp., 1992.

Paasche, E.: Silicon and the ecology of marine plankton diatoms. I. Thalassiosira pseudonana (Cyclotella nana) grown in a chemostat with silicate as the limiting nutrient, Mar. Biol., 19, 117-126, 1973

Petr, T.: Dissolved chemical transport in major rivers of Papua New Guinea, Mitt. Geol. Paläont. Inst., Univ. Hamburg, 55, 477-481, 1983.

Probst, J.-L.: Géochimie et Hydrochimie de l' érosion continentale. Mécanismes, bilan global actuel et fluctuations au cours des 500 derniers millions d'années, Sciences Géologiques Mémoires 94, Strasbourg, 161 pp., 1992.

Probst, J.-L., Mortatti, J., and Tardy, Y.: Carbon River Fluxes and Weathering $\mathrm{CO}_{2}$ consumption in the Congo and Amazon River Basins, Appl. Geochem., 9(1), 1-13, 1994.

Rabalais, N. N. and Turner, R. E. (Eds.): Coastal hypoxia, Coastal and Estuarine Studies Series 58, American Geophysical Union, Washington DC, 2001.

Rabouille, C., Mackenzie, F. T., and Ver, L. M.: Influence of the human perturbation on carbon, nitrogen, and oxygen biogeochemical cycles in the global coastal ocean, Geochim. Cosmochim. Ac., 65(21), 3615-3641, 2001.

Ragueneau, O., Lancelot, C., Egorov, V., Vervlimmeren, J., Cociasu, A., Déliat, G., Krastev, A., Daoud, N., Rousseau, V., Popovitchev, V., Brion, N., Popa, L., and Cauwet, G.: Biogeochemical transformations of inorganic nutrients in the mixing zone between the Danube river and the northwestern Black Sea, Estuar. Coast. Shelf S., 54(3), 321-336, 2002.

Ragueneau, O., Chauvaud, L., Moriceau, B., Leynaert, A., Thouzeau, G., Donval, A., LeLoc'h, F., and Jean, F.: Biodeposition by an invasive suspension feeder impacts the biogeochem- ical cycle of $\mathrm{Si}$ in a coastal ecosystem (Bay of Brest, France), Biogeochemistry, 75(1), 19-41, doi:10.1007/s10533-004-56773, 2005.

Rendell, A. R., Horrobin, T. M., Jickells, T. D., Edmunds, H. M., Brown, J., and Malcolm, S. J.: Nutrient Cycling in the Great Ouse Estuary and its Impact on Nutrient Fluxes to The Walsh, England, Estuar. Coast. Shelf S., 45, 653-668, 1997.

Riebe, C. S., Kirchner, J. W., Granger, D. E., and Finkel, R. C.: Strong tectonic and weak climatic control of long-term chemical weathering rates, Geology, 29(6), 511-514, 2001.

Robinson, R. J. and Thompson, T. G.: The determination of silicate in sea water, J. Mar. Res., 7, 49-55, 1948.

Roth, J.: Allgemeine und chemische Geologie Band 1: Bildung und Umbildung der Mineralien - Quell-, Fluss,- und Meerwasser, Verlag von Wilhelm Hertz, Berlin, 633 pp., 1879.

Roth, J.: Allgemeine und Chemische Geologie, Dritter Band Zweite Abteilung: Verwitterung, Zersetzung und Zerstörung der Gesteine, Verlag von Wilhelm Hertz (Bessersche Buchhandlung), Berlin, 530 pp., 1893.

Roubeix, V., Rousseau, V., and Lancelot, C.: Diatom succession and silicon removal from freshwater in estuarine mixing zones: From experiment to modelling, Estuar. Coast. Shelf S., 78, 14 26, doi:10.1016/j.ecss.2007.11.007, 2007.

Saccone, L., Conley, D. J., and Sauer, D.: Methodologies for amorphous silica analysis, J. Geochem. Explor., 88, 235-238, 2006.

Schelske, C. L.: Biogeochemical silica mass balances in Lake Michigan and Lake Superior, Biogeochemistry, 1(3), 197-218, 1985

Schelske, C. L. and Stoermer, E. F.: Eutrophication, silica depletion, and predicted changes in algal quality in Lake Michigan, Science, 173, 423-424, 1971

Schlesinger, W. H.: Biogeochemistry: an analysis of global change, Academic Press, San Diego, 588 pp., 1997.

Seitzinger, S. P., Harrison, J. A., Dumont, E., Beusen, A. H W., and Bouwman, A. F.: Sources and delivery of carbon, nitrogen, and phosphorus to the coastal zone: an overview of Global Nutrient Export from Watersheds (NEWS) models and their application, Global Biogeochem. Cy., 19, GB4S01, doi:10.1029/2005GB002606, 2005.

Sferratore, A., Billen, G., Garnier, J., and Théry, S.: Modelling Nutrient (N,P,Si) Budget in the Seine Watershed: Application of the Riverstrahler Model using Data from Local to Global Scale Resolution, Global Biogeochem. Cy., 19, GB4S07, doi:10.1029/2005GB002496, 2005.

Sferratore, A., Garnier, J., Billen, G., Conley, D. J., and Pinault, S.: Diffuse and point sources of silica in the Seine River watershed, Environ. Sci. Technol., 40, 6630-6635, 2006.

Smith, S. V. and Hollibaugh, J. T.: Role of coastal ocean organic metabolism in the oceanic organic carbon balance, Rev. Geophys., 31, 75-89, 1993

Stallard, R. F.: Tectonic, environmental, and human aspects of weathering and erosion: A Global Review using a Steady-State Perspective, Annu. Rev. Earth Pl. Sc., 23, 11-39, 1995.

Stallard, R. F.: Terrestrial sedimentation and the carbon cycle: coupling weathering and erosion to carbon burial, Global Biogeochem. Cy., 12(2), 231-257, 1998

St. Louis, V. L., Kelly, C. A., Duchemin, E., Rudd, J. W. M., and Rosenberg, D. M.: Reservoir Surfaces as Sources of Greenhouse Gases to the Atmosphere: A Global Estimate, BioScience, 50(9), 
766-775, 2000.

Straskrabova, V., Kennedy, R. H., Lind, O. T., Tundisi, J. G., and Hejzlar, J. (Eds.): Reservoir limnology and water quality, Hydrobiologia, vol. 504, Kluwer Academic, Dordrecht, 325 pp., 2003.

Strickland, J. D. H. and Parsons, T. R.: A practical handbook of seawater analysis, B. Fish. Res. Board Can., 167, 1-311, 1968.

Struyf, E., Smis, A., Van Damme, S., Garnier, J., Govers, G., Van Wesemael, B., Conley, D. J., Batelaan, O., Frot, E., Clymans, W., Vandevenne, F., Lancelot, C., Goos, P., and Meire, P.: Historical land use change has lowered terrestrial silica mobilization, Nat. Commun., 1(8), 129, doi:10.1038/ncomms1128, 2010.

Subramanian, V.: Mineralogical input of suspended matter by Indian rivers into the adjacent areas of the Indian Ocean, Mar. Geol., 36, 29-34, 1980.

Syvitski, J. P. M., Vörösmarty, C. J., Kettner, A. J., and Green, P.: Impact of humans on the flux of terrestrial sediment to the global coastal ocean, Science, 308, 376-380, 2005.

Tegen, I. and Kohfeld, K. E.: Atmospheric Transport of Silicon, in: The Silicon Cycle - Human Perturbations and Impacts on Aquatic Systems, edited by: Ittekot, V., Unger, D., Humborg, C., and Tac An, N., SCOPE 66, Island Press, Washington, 81-92, 2006.

Teodoru, C., McGinnis, D. E., Wüest, A., and Wehrli, B.: Nutrient retention in the Danube's Iron Gate reservoir, EOS, 87(38), 385 and 392, 2006.

Tréguer, P., Nelson, D. M., Van Bennekom, A. J., DeMaster, D. J., Leynaert, A., and Quéguiner, B.: The Silica Balance in the World Ocean: A Reestimate, Science, 268, 375-379, 1995.

Van Cappellen, P.: Biomineralization and global biogeochemical cycles, Rev. Mineral. Geochem., 54, 357-381, 2003.

van Dokkum, H. P., Hulskotte, J. H. J., Kramer, K. J. M., and Wilmot, J.: Emission, fate and effects of soluble silicates (waterglass) in the aquatic environment, Environ. Sci. Technol., 38, 515-521, 2004.

Viers, J., Dupré, B., and Gaillardet, J.: Chemical composition of suspended sediments in World Rivers: New insights from a new database, Sci. Total Environ., 407, 853-868, doi:10.1016/j.scitotenv.2008.09.053, 2009.

Viglieri, A.: Oceans: limits, definitions, dimensions, in: The Encyclopedia of Oceanography, edited by: Fairbridge, R. W., Van Nostrand Rheinhold, New York, 632-640, 1966.

Vörösmarty, C. J. and Meybeck, M.: Responses of continental aquatic systems at the global scale: new paradigms, new methods, in: Vegetation, Water, Humans and the Climate, edited by: Kabat, P., Claussen, M., Dirmeyer, P. A., Gash, J. H. C., Bravo de Guenni, L., Meybeck, M., Pielke, R. A., Vörösmarty, C. J., Hutjes, R. W. A., and Lütkemeier, S., Springer, Berlin, 375-413, 2004.
Vörösmarty, C. J., Sharma, K., Fekete, B., Copeland, A. H., Holden, J., Marble, J., and Lough, J. A.: The storage and aging of continental runoff in large reservoir systems of the world, Ambio, 26, 210-219, 1997.

Vörösmarty, C. J., Fekete, B. M., Meybeck, M., and Lammers, R. B.: The global system of rivers: its role in organizing continental land mass and defining land-to-ocean linkages, Global Biogeochem. Cy., 14(2), 599-621, 2000a.

Vörösmarty, C. J., Fekete, B. M., Meybeck, M., and Lammers, R. B.: Geomorphometric attributes of the global system of rivers at 30-minute spatial resolution, J. Hydrol., 237, 17-39, $2000 \mathrm{~b}$.

Vörösmarty, C. J., Meybeck, M., Fekete, B., Sharma, K., Green, P., and Syvitski, J.: Anthropogenic sediment retention: major global-scale impact from the population of registered impoundments, Global Planet. Change, 39, 169-190, 2003.

Walling, D. E.: The sediment delivery problem, J. Hydrol., 65, 209237, 1983

Walling, D. E. and Webb, B. W.: Erosion and sediment yield: a global overview, in: Erosion and sediment yield: global and regional perspectives, edited by: Walling, D. E. and Webb, B. W., Exeter: IAHS publication, 236, 3-19, 1996.

Webster, I. T., Parslow, J. S., and Smith, S. V.: Implications of Spatial and Temporal Variation for Biogeochemical Budgets of Estuaries, Estuaries, 23(3), 341-350, 2000.

West, A. J., Galy, A., and Bickle, M.: Tectonic and climatic controls on silicate weathering, Earth Planet. Sc. Lett., 235, $211-$ 228, 2005.

Wetzel, R. G.: Limnology: lake and river ecosystems, Academic Press, San Diego, 1006 pp., 2001.

White, A. F. and Blum, A. E.: Effects of climate on chemicalweathering in watersheds, Geochim. Cosmochim. Ac., 59(9), 1729-1747, 1995.

Wollast, R. and Mackenzie, F. T.: The global cycle of silica, in: Silicon geochemistry and biogeochemistry, edited by: Aston, S. E., Academic Press, London, 39-76, 1983.

Yamada, S. S. and D'Elia, C. F.: Silicic acid regeneration from estuarine sediment cores, Mar. Ecol.-Prog. Ser., 18, 113-118, 1984.

Zanke, U.: Basics of sediment transport (in German: "Grundlagen der Sedimentbewegung"), Berlin-Heidelberg-New York, Springer-Verlag, XII, 402 pp., 1982.

Zhang, J., Zhang, G. S., and Liu, S. M.: Dissolved silicate in coastal marine rainwaters: comparison between the Yellow Sea and the East China Sea on the impact and potential link with primary production, J. Geophys. Res.-Atmos., 110, D16304, doi:10.1029/2004JD005411, 2005. 